\title{
Atmospheric nucleation: highlights of the EUCAARI project and future directions
}

V.-M. Kerminen ${ }^{1,2}$, T. Petäjä ${ }^{1}$, H. E. Manninen ${ }^{1}$, P. Paasonen ${ }^{1}$, T. Nieminen ${ }^{1}$, M. Sipilä ${ }^{1}$, H. Junninen ${ }^{1}$, M. Ehn ${ }^{1}$, S. Gagné ${ }^{1}$, L. Laakso ${ }^{12,1}$, I. Riipinen ${ }^{1,13}$, H. Vehkamäki ${ }^{1}$, T. Kurten ${ }^{1}$, I. K. Ortega ${ }^{1}$, M. Dal Maso ${ }^{1,6}$, D. Brus ${ }^{2}$, A. Hyvärinen ${ }^{2}$, H. Lihavainen ${ }^{2}$, J. Leppä ${ }^{2}$, K. E. J. Lehtinen ${ }^{2,11}$, A. Mirme ${ }^{3}$, S. Mirme ${ }^{3}$, U. Hõrrak ${ }^{3}$, T. Berndt ${ }^{4}$, F. Stratmann ${ }^{4}$, W. Birmili ${ }^{4}$, A. Wiedensohler ${ }^{4}$, A. Metzger $^{5,}{ }^{*}$, J. Dommen $^{5}$, U. Baltensperger ${ }^{5}$, A. Kiendler-Scharr ${ }^{6}$, T. F. Mentel ${ }^{6}$, J. Wildt ${ }^{6}$, P. M. Winkler ${ }^{7, * *}$, P. E. Wagner ${ }^{7}$, A. Petzold ${ }^{8}$, A. Minikin ${ }^{8}$, C. Plass-Dülmer ${ }^{9}$, U. Pöschl ${ }^{10}$, A. Laksonen ${ }^{1,11}$, and M. Kulmala ${ }^{1}$

${ }^{1}$ Department of Physics, P.O. Box 64, 00014 University of Helsinki, Finland

${ }^{2}$ Finnish Meteorological Institute, Research and Development, P.O. Box 503, 00101 Helsinki, Finland

${ }^{3}$ Institute of Physics, University of Tartu, Ülikooli 18, 50090, Tartu, Estonia

${ }^{4}$ Leibniz-nstitute für Troposphärenforschung, Permoserstrasse 15, Leipzig 04318, Germany

${ }^{5}$ Laboratory of Atmospheric Chemistry, Paul Scherrer Institut, 5232 Villigen PSI, Switzerland

${ }^{6}$ Institut für Chemie und Dynamik der Geosphäre (ICG), Forschungszentrum Jülich, 52425 Jülich, Germany

${ }^{7}$ Fakultät für Physik, Universität Wien, Boltzmanngasse 5, 1090 Wien, Austria

${ }^{8}$ Deutsches Zentrum für Luft- und Raumfarhr, Institut für Physik der Atmosphäre, Oberpfaffenhofen, Germany

${ }^{9}$ Hohenpeissenberg Meteorological Observatory, Deutscher Wetterdienst, Germany

${ }^{10}$ Max Planck Institute for Chemistry, Biogeochemistry Department, P.O. Box 3060, 55128 Mainz, Germany

${ }^{11}$ Department of Physics and Mathematics, University of Eastern Finland, P.O. Box 1627, 70211 Kuopio, Finland

${ }^{12}$ School of Physical and Chemical Sciences, North-West University, Potchefstroom, South Africa

${ }^{13}$ Department of Chemical Engineering, Carnegie Mellon University, 15213, Pittsburgh, PA, USA

* now at: Ionicon Analytik GmbH, 6020 Innsbruck, Austria

** now at: Atmospheric Chemistry Division, National Center for Atmospheric Research, 1850 Table Mesa Dr., Boulder, CO-80305, USA

Received: 24 May 2010 - Published in Atmos. Chem. Phys. Discuss.: 2 July 2010

Revised: 28 September 2010 - Accepted: 8 November 2010 - Published: 18 November 2010

\begin{abstract}
Within the project EUCAARI (European Integrated project on Aerosol Cloud Climate and Air Quality interactions), atmospheric nucleation was studied by (i) developing and testing new air ion and cluster spectrometers, (ii) conducting homogeneous nucleation experiments for sulphate and organic systems in the laboratory, (iii) investigating atmospheric nucleation mechanism under field conditions, and (iv) applying new theoretical and modelling tools for data interpretation and development of parameterisations. The current paper provides a synthesis of the obtained results and identifies the remaining major knowledge gaps related to atmospheric nucleation. The most important technical achievement of the project was the development of new in-
\end{abstract}

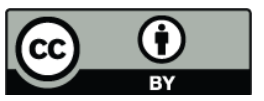

Correspondence to: V.-M. Kerminen (veli-matti.kerminen@fmi.fi) struments for measuring sub-3 $\mathrm{nm}$ particle populations, along with the extensive application of these instruments in both the laboratory and the field. All the results obtained during EUCAARI indicate that sulphuric acid plays a central role in atmospheric nucleation. However, also vapours other than sulphuric acid are needed to explain the nucleation and the subsequent growth processes, at least in continental boundary layers. Candidate vapours in this respect are some organic compounds, ammonia, and especially amines. Both our field and laboratory data demonstrate that the nucleation rate scales to the first or second power of the nucleating vapour concentration(s). This agrees with the few earlier field observations, but is in stark contrast with classical thermodynamic nucleation theories. The average formation rates of 2-nm particles were found to vary by almost two orders of magnitude between the different EUCAARI sites, whereas the formation rates of charged 2-nm particles varied very

Published by Copernicus Publications on behalf of the European Geosciences Union. 
little between the sites. Overall, our observations are indicative of frequent, yet moderate, ion-induced nucleation usually outweighed by much stronger neutral nucleation events in the continental lower troposphere. The most concrete outcome of the EUCAARI nucleation studies are the new semiempirical nucleation rate parameterizations based on field observations, along with updated aerosol formation parameterizations.

\section{Introduction}

The recent decade of atmospheric measurements demonstrated nucleation to be a frequent phenomenon in the continental boundary layer, as well as in the free troposphere (Kulmala et al., 2004; Kulmala and Kerminen 2008, and references therein). Direct observational evidence was further received that particles nucleated in the atmosphere are able to grow into cloud condensation nuclei (CCN) sizes (O'Dowd, 2001; Lihavainen et al., 2003; Kuwata et al., 2005; Laaksonen et al., 2005; Whitehead et al., 2009; Wiedensohler et al., 2009) and ultimately to form cloud droplets (Kerminen et al., 2005). Model simulations suggest that nucleation is very likely the dominant source of the particle number concentration in the global atmosphere (Spracklen et al., 2006; Yu and Luo, 2009), and that it is a significant contributor to global CCN concentrations (Spracklen et al., 2008; Merikanto et al., 2009; Pierce and Adams, 2009; Yu and Luo, 2009) and cloud droplet number concentrations (Makkonen et al., 2009; Wang and Penner, 2009; Kazil et al., 2010).

In spite of its evident importance in the global aerosol system, climatic and other influences of atmospheric nucleation have turned out to be very difficult to quantify. Several reasons for this can be identified. First of all, our inability to measure neutral sub- $3 \mathrm{~nm}$ diameter particles, until very recently, has hampered the interpretation of both field and laboratory experiments (e.g., Sipilä et al., 2008, 2009, 2010). Second, beside sulphuric acid, it is still not known which vapours take part in atmospheric nucleation and to which extent (e.g., Smith et al., 2008; Claeys et al., 2009). Third, the role of ions in atmospheric nucleation has remained ambiguous (e.g., Iida et al., 2006, Kazil et al., 2008; Yu and Turco, 2008; Yu, 2010). The lack of a proper mechanistic understanding of atmospheric nucleation has made it difficult to develop reliable aerosol formation parameterisations for large-scale modelling frameworks - the ultimate tools to address the role of nucleation in climate and air quality issues.

Due to the reasons highlighted above, nucleation studies were given a high priority in the ongoing project EUCAARI (European Integrated project on Aerosol Cloud Climate and Air Quality interactions; Kulmala et al., 2009). The overall goal of these studies was to produce parameterised representations of nucleation processes for sulphuric acid-ammonia- water, organic and iodine oxide systems based on combined information from nucleation theories, modelling and experimental studies, to be used in regional and global scale models. The problem was approached by (i) developing and testing new ion and cluster spectrometers, (ii) conducting homogeneous nucleation experiments for sulphate and organic systems in the laboratory, (iii) investigating atmospheric nucleation mechanism under field conditions, and (iv) applying new theoretical and modelling tools for data interpretation and development of parameterisations. In the following sections we will summarize our main results from nucleation studies conducted within the EUCAARI project, after which a brief scientific synthesis with concluding remarks will be presented.

\section{Development of instrumentation}

The main emphasis in the instrumental development within EUCAARI was put on the detection of sub- $3 \mathrm{~nm}$ neutral particles/clusters. For this purpose, an entirely new air ion spectrometer was designed, built, tested and calibrated. Major developments were also achieved with regard of measurement capabilities and application of various condensation particle counters, and a new way of applying the mobility size spectrometer technique for obtaining information about ioninduced nucleation was introduced. Finally, we were able to measure the chemical composition of atmospheric ions with high-resolution mass spectrometric methods.

\subsection{Neutral cluster and Air Ion Spectrometer (NAIS)}

During EUCAARI, a new prototype ion spectrometer, termed NAIS (Neutral cluster and Air Ion Spectrometer, Kulmala et al., 2007a; Manninen et al., 2009a) was developed. The NAIS builds on the Air Ion Spectrometer (AIS, Mirme et al., 2007), following the principle of multi-channel parallel electrical aerosol spectrometry. The NAIS is able to measure the concentrations and size distributions of both neutral and charged particles in 21 size fractions (channels). The mobility range of the NAIS is $3.2-0.0013 \mathrm{~cm}^{2} \mathrm{~V}^{-1} \mathrm{~s}^{-1}$, corresponding to a mobility diameter (Millikan-Fuchs equivalent diameter) range of $0.8-42 \mathrm{~nm}$. In case of neutral particles, the lowest measurable size is in practice about $2 \mathrm{~nm}$ due to the presence of charger ions with mobilities of 1.3$1.6 \mathrm{~cm}^{2} \mathrm{~V}^{-1} \mathrm{~s}^{-1}$ (Wiedensohler, 1988; Asmi et al., 2009). The NAIS operates at a five-minute time resolution in order to optimize the sensitivity and signal-to-noise ratio.

The overall performance of the NAIS was tested under both laboratory and field condition in Tartu, Estonia. In the laboratory tests, well-defined cluster ions, aerosol ions and neutral aerosol particles were used. The first air ion spectrometer calibration and inter-comparison workshop was then organised in Helsinki, Finland. The workshop took place in January-February, 2008, just prior to the EUCAARI 
Intensive Observation Period (Asmi et al., 2009). In the workshop, ten ion spectrometers, including four NAIS instruments, were compared and calibrated. Calibrations were made with mobility standards (see Ude and de La Mora, 2005) and silver particles by using high-resolution differential mobility analysers (HDMA, Hermann et al., 2007). The monodisperse mobility distribution broadened to approximately 3-5 size channels when measured by the ion spectrometers due to the strong diffusion of these small ions. Particle sizes detected by the ion spectrometers were slightly smaller (30-50\% larger mobilities) than those characterized with the HDMA. Excluding some overestimation at the smallest sizes, ion concentrations measured by the spectrometers were in good agreement with those measured by the aerosol electrometer and condensation particle counter.

The NAIS was developed further in order to extend its operation to variable altitudes, including its airborne operation. The development aimed at the improved control and automatic tuning of air flows and other instrument operation parameters following the variations of ambient conditions. The NAIS was tested in airborne measurements during the EUCAARI long-range experiment EUCAARI LONGREX 2008. The NAIS performed very well during the flights (Mirme et al., 2010). The effects of varying pressure and temperature as a function of flight height were taken into account by automatically adjusting the sheath flow of the instrument, which kept the volumetric sampling flow rate constant. Furthermore, the variability of the charger ion mobility was compensated by adjusting the corona current. The NAIS was capable of automatically adapting to variations of barometric pressure from the surface level up to the $8-\mathrm{km}$ altitude without any additional corrections. At higher altitudes, the measured size distribution was corrected in the post-processing phase (Mirme et al., 2010).

The NAIS is the first instrument, from which the formation rates of both neutral and charged sub- $3 \mathrm{~nm}$ diameter particles can be determined. By writing the balance equation for 2$3 \mathrm{~nm}$ particles and rearranging the terms, the total formation rate of 2-nm particles $\left(J_{2}\right)$ is obtained from (Kulmala et al., 2007a; Manninen et al., 2009b):

$J_{2}=\frac{\mathrm{d} N_{2-3}}{\mathrm{~d} t}+\mathrm{CoagS}_{2} \times N_{2-3}+\frac{f}{1 \mathrm{~nm}} \mathrm{GR}_{3} N_{2-3}$.

Here $N_{2-3}$ is the total concentration of particles in the size range $2-3 \mathrm{~nm}, \mathrm{CoagS}_{2}$ is the coagulation sink of 2-nm particles, and $\mathrm{GR}_{3}$ is the particle growth rate at $3 \mathrm{~nm}$ and $f$ presents a fraction of $2-3 \mathrm{~nm}$ particles that has been activated for the growth (assumed equal to unity without a better knowledge). Since the particle number size distribution in the size range $2-3 \mathrm{~nm}$ is not known, we cannot calculate the exact rate at which particles in this size range are lost by coagulation with pre-existing larger particles. As a result, we use $\mathrm{CoagS}_{2}$ as an approximation to this loss rate, which may lead to a slight over-prediction of the value of $J_{2}$.
In case of charged particles, the ion-ion recombination and charging of $2-3 \mathrm{~nm}$ neutral particles need to be taken into account, after which their formation rate at $2 \mathrm{~nm}$ becomes:

$$
\begin{aligned}
J_{2}^{ \pm} & =\frac{\mathrm{d} N_{2-3}^{ \pm}}{\mathrm{d} t}+\mathrm{CoagS}_{2} \times N_{2-3}^{ \pm}+\frac{f}{1 \mathrm{~nm}} \mathrm{GR}_{3} N_{2-3}^{ \pm} \\
& +\alpha N_{2-3}^{ \pm} N_{<3}^{\mp}-\beta N_{2-3} N_{<2}^{ \pm} .
\end{aligned}
$$

Here the superscript \pm refers to positively and negatively charged particles and $N_{2-3}^{ \pm}, N_{<2}^{ \pm}$and $N_{<3}^{ \pm}$are the corresponding ion concentrations in the size range $2-3 \mathrm{~nm}$, below $2 \mathrm{~nm}$ and below $3 \mathrm{~nm}$, respectively. The ion-ion recombination coefficient, $\alpha$, and the ion-neutral attachment coefficient, $\beta$, can be assumed to be equal to $1.6 \times 10^{-6} \mathrm{~cm}^{3} \mathrm{~s}^{-1}$ and $0.01 \times 10^{-6} \mathrm{~cm}^{3} \mathrm{~s}^{-1}$, respectively (e.g. Tammet and Kulmala, 2005). The last two terms in the right hand side of Eq. (2) are not exact but rather provide a first order correction for the formation rate due to ion-ion recombination and ion-aerosol attachment, respectively. Used together, Eqs. (1) and (2) make it possible to estimate the contribution of ioninduced nucleation to the total nucleation rate, as will be demonstrated in Sect. 4.2.

\subsection{Condensation particle counters}

A Condensation Particle Counter (CPC) is a widely-used instrument to detect the number concentration of aerosol particles too small to be observed with optical techniques (McMurry, 2000). The CPC is able to monitor concentrations of both charged and neutral particles, although the experiments show that the charge carried by the particle enhances the detection efficiency (Winkler et al., 2008a, b).

The instrumental development has improved the detection efficiency (D50) of the CPCs defined as the size, where 50\% of the sampled particles are detected. In the CPC design, the work by Stolzenburg and McMurry (1991) was a milestone, as they presented a counter capable of detecting particles down to $3 \mathrm{~nm}$ in diameter. The detection efficiency of a CPC depends in general on the generated supersaturation inside the CPC, which determines the smallest particle size that is activated to growth. Already Mertes et al. (1995) showed that for a butanol based CPC, the value of D50 can be decreased by increasing the supersaturation inside the CPC. Petäjä et al. (2006) showed that this applies also to a waterbased CPC (Hering et al., 2005). The limiting factor is the onset of homogeneous nucleation of the CPC working fluid.

The supersaturation at the onset of homogeneous nucleation depends on thermodynamic properties of the working fluid, and the detection efficiency of the CPC can be improved by selection of the working fluid (Iida et al., 2009). The CPC performance can also be improved by minimizing the losses of the small particles. As part of EUCAARI, Vanhanen et al. (2010) combined the rapid mixing type CPC (Sgro and de la Mora, 2004) with a diethylene glycol based CPC and showed that in their design the diffusion losses dominate the detection efficiency down to molecular sizes 
(diameter $\sim 1 \mathrm{~nm}$ ). In other words, given that the sampled particles are not lost during the sampling process, the instrument developed by Vanhanen et al. (2010) is able to detect particles down to $1 \mathrm{~nm}$ in size.

The onset of homogeneous nucleation does not necessarily restrain the use of a CPC in atmospheric measurements. Kulmala et al. (2005) used a UF02-proto CPC (Mordas et al., 2005, 2008) as a nucleation chamber. By subtracting the contribution of homogeneous nucleation inside the CPC, they were able to probe the ambient sub- $3 \mathrm{~nm}$ particle concentration. During EUCAARI, this approach was further developed by Sipilä et al. (2008, 2009), who utilized the pulse-height (PH) analysis (Saros et al., 1996; Weber et al., 1996) in differentiating the signals originating from the homogeneously nucleated working fluid and the ambient sample. Lehtipalo et al. (2009) measured the concentration of sub-3 $\mathrm{nm}$ particles in a boreal forest by using a tuned $\mathrm{PH}$ $\mathrm{CPC}$. The estimated concentrations varied from $5 \times 10^{2}$ to $5 \times 10^{4}$ clusters $\mathrm{cm}^{-3}$, which is more than what one would expect from the recombination of ion clusters.

The detection efficiency of the CPC depends also on the chemical composition of the sampled particles. For example, water solubility and wetability increase the detection efficiency of inorganic salt particles compared with nonhygroscopic silver particles (Petäjä et al., 2006; Herman et al., 2007). In terms of reliable and reproducible number concentration measurements, this is a drawback, especially in environments where a lot of nucleation mode particles are present. This disadvantage was turned into a benefit by Kulmala et al. (2007b) who applied a battery of CPCs (CPCB) with different working fluids in parallel. Furthermore, Riipinen et al. (2009) utilized the CPCB in the boreal forest to probe the composition of $2-9 \mathrm{~nm}$ particles by looking into their water solubility. The results showed that during newparticle formation, the initially more hygroscopic particles grew in size by condensation of less water soluble material.

\subsection{Ion-Differential Mobility Particle Sizer (Ion-DMPS)}

Traditionally, aerosol number size distributions are measurements with mobility size spectrometers such as the DMPS or SMPS (Differential/Scanning Mobility Particle Sizer; Hoppel, 1978; Wang and Flagan, 1990; Aalto et al., 2001). The mobility size spectrometer relies on the fact that the sampled particles have a known charge distribution (Wiedensohler, 1988). This can be acquired with a radioactive source, which provides an excess amount of both negative and positive ions that either charge or neutralize the sampled particle population depending on the initial charging state. The residence time of the air sample in the bipolar charger is long enough for the sample to reach the known, steady-state charge distribution.

In EUCAARI, a new instrument called the Ion-DMPS was introduced and also applied in field (Laakso et al., 2007a). The radioactive source of the Ion-DMPS can be by-passed on demand, which enables the measurement of either the atmospheric ion number size distribution or of the corresponding size distribution of a neutralized aerosol sample. By comparing these two modes of operation, a size-dependent charging state is obtained (Laakso et al., 2007a; Gagné et al., 2008). The value of the charging state is larger than unity when the population of particles of a given size is more charged than in the stationary state corresponding to the neutralized aerosol sample. In such a case the particle population is called overcharged. Similarly, an undercharged particle population has a charging state smaller than unity. The Ion-DMPS measures the charging state for both negative and positive polarities.

The charging state obtained from the Ion-DMPS provides information about the participation of ion-induced nucleation in new-particle formation: a measured charging state $>1$ suggests at least some contribution by ion-induced nucleation, whereas a charging state $<1$ indicates no or minor contribution by ion-induced nucleation (Laakso et al., 2007a). For a more quantitative statement, we need to apply the theoretical framework developed by Kerminen et al. (2007). According to this work, the charging state of a growing nucleation mode is governed by its initial charging state, atmospheric cluster ion concentration, and the growth rate of the nucleation mode. In practice this can be interpreted as follows: regardless of the nucleation mechanism, growing nuclei are exposed to collisions with atmospheric cluster ions, as a result of which the charging state of the growing nuclei population is changed. If the nuclei growth rate is slow, e.g. due to a low concentration of condensable vapours, the information on the initial charging state will be lost by the time the IonDMPS detects the growing clusters. On the other hand, if the nuclei growth is rapid enough and the atmospheric cluster ion concentration is low enough, the analytical formulae presented by Kerminen et al. (2007), together with Ion-DMPS data, can be used to extract the relative roles of ion-induced and neutral nucleation mechanisms in observed new-particle formation events. The application of the Ion-DMPS under field conditions will be discussed in Sect. 4.2.

\subsection{Atmospheric Pressure Interface Time of Flight Mass Spectrometer (APi-TOF)}

Mass spectrometric techniques can provide insights into the composition of atmospheric ions and clusters (Eisele, 1989a, b; Eichkorn et al., 2002; Junninen et al., 2010; Zhao et al., 2010). Within EUCAARI, we tested an Atmospheric Pressure Interface Time-of-Flight Mass Spectrometer (APi-TOF, Tofwerk AG), the mass/charge (in unit Th) range of which extends up to $2000 \mathrm{Th}$ (Junninen et al., 2010). With the high mass accuracy $(<20 \mathrm{ppm})$ and mass resolving power $(3000 \mathrm{Th} / \mathrm{Th})$, the APi-TOF makes it possible to determine the composition of small atmospheric ions. The ions were identified based on their high-resolution masses, isotopic patterns and peak-to-peak correlograms. Potential candidates were also judged based on proton affinities and quantum 
chemical considerations (Junninen et al., 2010; Ehn et al., 2010).

The operation of the APi-TOF at an urban site in Helsinki and in a rural environment in Hyytiälä, Finland revealed a considerable diurnal variability in the chemical composition of ions and their clusters (Junninen et al., 2010; Ehn et al., 2010). The driving factors were photochemical production of various ions and their proton affinity. In the atmospheric ion population the charge is transferred to molecules with the highest (positive ions) and lowest proton affinities (negative ions). Thus, during daytime the negative ions were dominated by strong acids (e.g. sulfuric and malonic acid) and their clusters. During night, nitric acid and organic acids were the dominant peaks in the negative spectrum. For the first time an organo-sulphate (glycolic acid sulphate) was detected in the gas phase (Ehn et al., 2010). The diurnal cycle was less pronounced in the positive spectrum, which was dominated by strong bases (alkyl pyridines, quinolines and amines). A detailed description of the API-TOF and first results can be found in Junninen et al. (2010) and Ehn et al. (2010).

\section{Laboratory experiments}

Within EUCAARI, homogeneous nucleation experiments were conducted in three laboratories using two different flow tubes and a smog chamber. Homogeneous nucleation experiments were made for the binary sulphuric acid-water system $\left(\mathrm{H}_{2} \mathrm{SO}_{4}-\mathrm{H}_{2} \mathrm{O}\right)$, for the ternary sulphuric acid-waterammonia system $\left(\mathrm{H}_{2} \mathrm{SO}_{4}-\mathrm{H}_{2} \mathrm{O}-\mathrm{NH}_{3}\right)$, and for various systems including both sulphuric acid and organic compounds $\left(\mathrm{H}_{2} \mathrm{SO}_{4}-\mathrm{Org}\right)$. The binary $\mathrm{H}_{2} \mathrm{SO}_{4}-\mathrm{H}_{2} \mathrm{O}$ system was given a high priority because (i) it is the most widely-studied atmospheric nucleation mechanism, (ii) even today only few large-scale atmospheric models include any other nucleation mechanism in their simulations, and (iii) laboratory experiments concerning this system have turned out to be very difficult to conduct and interpret (Berndt et al., 2005, 2008; Benson et al., 2008). The ternary $\mathrm{H}_{2} \mathrm{SO}_{4}-\mathrm{H}_{2} \mathrm{O}-\mathrm{NH}_{3}$ system was selected because ammonia, being the dominant base to neutralize atmospheric sulphate particles (Bowman et al., 1997), is also the most obvious candidate for enhancing sulphuric acid-water nucleation (see Merikanto et al., 2007, and references therein). The $\mathrm{H}_{2} \mathrm{SO}_{4}$-Org system was selected (i) because organic compounds are known to play a significant role in nuclei growth (e.g. Smith et al., 2008), and thus one might expect them to be involved in the nucleation process as well, and (ii) because very few laboratory experiments on this system have been conducted so far (Zhang et al., 2004). In addition to homogenous nucleation, a series of heterogeneous nucleation experiments were made for both neutral and charged particles and clusters.

\subsection{Binary sulphuric acid-water nucleation}

The binary sulphuric acid-water nucleation experiments were performed in the Leibniz Institute for Tropospheric Research laminar flow tube (IfT-LFT) and in the Finnish Meteorological Institute (FMI) laminar flow tube (Sipilä et al., 2010). Two types of experiments were conducted: (i) experiments where $\mathrm{H}_{2} \mathrm{SO}_{4}$ was produced in situ via the reaction of $\mathrm{OH}$ radicals with $\mathrm{SO}_{2}$ ("photolysis" experiments), and (ii) experiments where $\mathrm{H}_{2} \mathrm{SO}_{4}$ was taken from a liquid sample ("liquid-sample" experiments). In both cases, the $\mathrm{H}_{2} \mathrm{SO}_{4}$ concentration was measured directly using a chemical ionization mass spectrometer (Petäjä et al., 2009). Another specific feature associated with these experiments was that nucleated particles were measured down to $1.3-1.5 \mathrm{~nm}$ in mobility diameter. This was achieved with the help of a modified pulse height analyzing ultrafine condensation particle counter and, in some experiments, with a mixing type particle size magnifier (Sipilä et al., 2010).

Earlier studies on $\mathrm{H}_{2} \mathrm{SO}_{4}-\mathrm{H}_{2} \mathrm{O}$ nucleation reported a clear disagreement between the photolysis and liquid-sample experiments, being several orders of magnitude in the nucleation rate and a couple of orders of magnitude in the onset $\mathrm{H}_{2} \mathrm{SO}_{4}$ concentration required for a nucleation rate of $1 \mathrm{~cm}^{-3} \mathrm{~s}^{-1}$ (Benson et al., 2008; Berndt et al., 2008). The experiments conducted within EUCAARI demonstrate that this disagreement is largely a measurement artifact arising from the high sensitivity of the measured "nucleation rate" to: (i) the temporal and spatial profile of the gaseous $\mathrm{H}_{2} \mathrm{SO}_{4}$ concentration inside the measurement device and (ii) the detection efficiency of the instrument used to measure nucleated particles. When minimizing the influence of these two effects in the experiments, practically no difference in the nucleation rate between the photolysis and liquid-sample experiments was observed any more (Sipilä et al., 2010).

The new $\mathrm{H}_{2} \mathrm{SO}_{4}-\mathrm{H}_{2} \mathrm{O}$ nucleation experiments are in line with EUCAARI field observations (Fig. 1). They both predict a slope between about 1 and 2 in a plot of the nucleation rate versus gaseous $\mathrm{H}_{2} \mathrm{SO}_{4}$ concentration, and require roughly the same amount of $\mathrm{H}_{2} \mathrm{SO}_{4}$ to initiate the nucleation process. These findings indicate (1) that particles are very likely formed via a similar $\mathrm{H}_{2} \mathrm{SO}_{4}$-driven nucleation mechanism in both the laboratory and the ambient atmosphere, and (2) that according to the nucleation theorem, critical clusters formed in the nucleation process contain only one or two $\mathrm{H}_{2} \mathrm{SO}_{4}$ molecules. Both laboratory and field measurements could be explained by either activation-type (Kulmala et al., 2006) or kinetic (McMurry and Friedlander, 1979) nucleation, but not by the thermodynamic binary $\mathrm{H}_{2} \mathrm{SO}_{4}-\mathrm{H}_{2} \mathrm{O}$ nucleation which predicts more than five $\mathrm{H}_{2} \mathrm{SO}_{4}$ molecules in a critical cluster under typical ambient conditions (e.g. Yu, 2008). This does not necessarily mean that existing binary $\mathrm{H}_{2} \mathrm{SO}_{4}-\mathrm{H}_{2} \mathrm{O}$ nucleation theories are wrong by themselves: it is possible that $\mathrm{H}_{2} \mathrm{SO}_{4}-\mathrm{H}_{2} \mathrm{O}$ nucleation is affected by the presence of impurities like ammonia, amines and various 


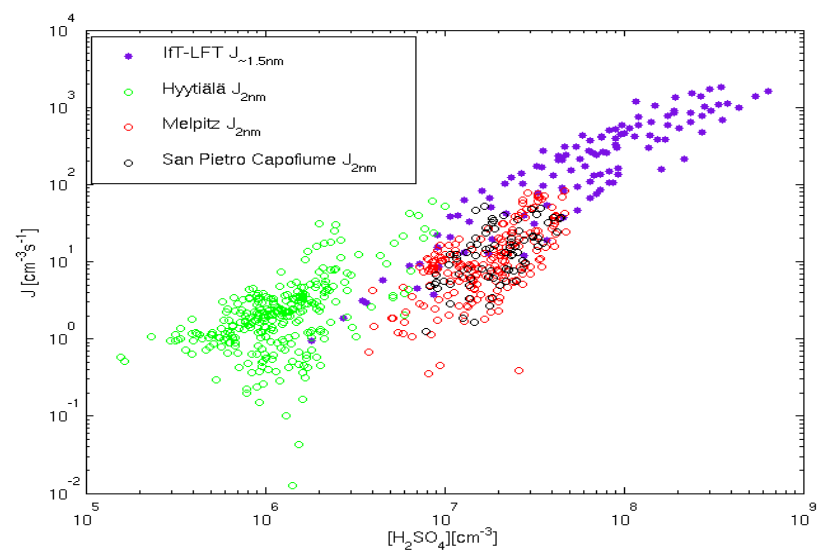

Fig. 1. Measured formation rate of 2-nm particles $\left(J_{2}\right)$ in different atmospheric locations (Hyytiälä, Melpitz and San Pietro Capofiume) and in a laminar flow reactor (IfT-LFT) as a function of measured sulfuric acid concentration.

organic compounds. Such compounds are practically always present in the atmosphere, and low level of these compounds (impurities) cannot be excluded from current laboratory experiments.

\subsection{Influence of ammonia and amines on sulphuric acid-water nucleation}

The ternary sulphuric acid-water-ammonia and sulphuric acid-water-amine nucleation experiments were performed in the Leibniz Institute for Tropospheric Research laminar flow tube (IfT-LFT; Berndt et al., 2005, 2010) at a temperature of $293 \pm 0.5 \mathrm{~K}$ by producing $\mathrm{H}_{2} \mathrm{SO}_{4}$ via the reaction of $\mathrm{OH}$ radicals with $\mathrm{SO}_{2}$. $\mathrm{NH}_{3}$ (Merck, $>99.9 \%$ ) was added to the carrier gas stream using a diluted sample from a gas metering unit. $\mathrm{NH}_{3}$ concentrations were measured at the inlet and outlet of the IfT-LFT by means of an OMNISENS TGA310 system (detection limit $2.5 \times 10^{9}$ molecules $\mathrm{cm}^{-3}$ ).

Figure 2 shows measured total particle number concentrations (TSI 3025) as a function of $\mathrm{H}_{2} \mathrm{SO}_{4}$ concentration in the absence $\left(\mathrm{NH}_{3}\right.$ concentration below $2.5 \times 10^{9}$ molecules $\mathrm{cm}^{-3}$, i.e. below about $100 \mathrm{ppt}$ ) and presence of $\mathrm{NH}_{3}$, and for different values of relative humidity. The inlet $\mathrm{NH}_{3}$ concentration was $1.2 \times 10^{12}$ molecules $\mathrm{cm}^{-3}$ in these experiments and, after an equilibration time of about one hour, the corresponding outlet concentration was $1.1 \times 10^{12}$ molecules $\mathrm{cm}^{-3}$. A distinct increase of the total particle number concentration with increasing relative humidity was observed when the $\mathrm{NH}_{3}$ concentration was below the detection limit. The enhancing effect of $\mathrm{NH}_{3}$ addition on the nucleation was found to be more pronounced under drier conditions, i.e. a factor of about 20 at a relative humidity of $13 \%$ and only a factor of about 2 at a relative humidity of $47 \%$. Experiments with different inlet $\mathrm{NH}_{3}$ concentrations showed that the presence of $\mathrm{NH}_{3}$

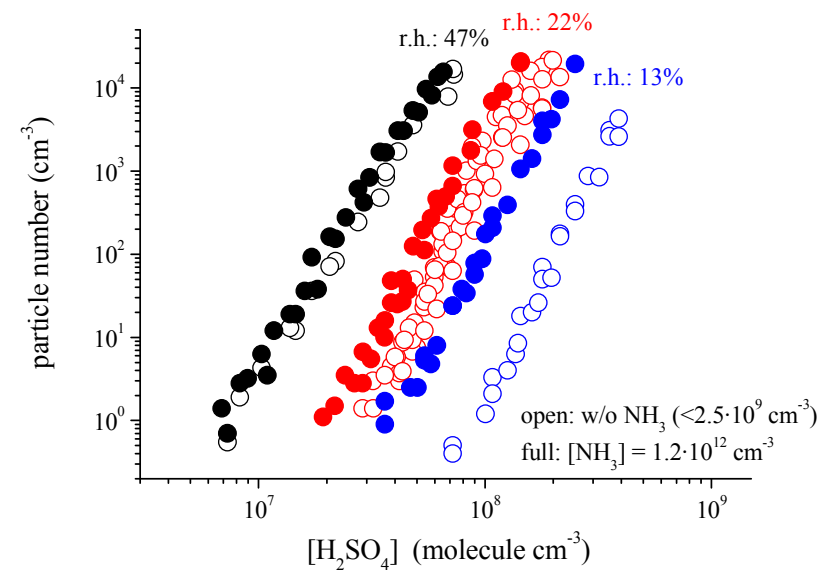

Fig. 2. Total particle number concentration as a function of the $\mathrm{H}_{2} \mathrm{SO}_{4}$ concentration in nucleation experiments made at different relative humidities $(\mathrm{RH})$. The experiments were conducted both in the presence of $\mathrm{NH}_{3}$ (full circles) and with $\mathrm{NH}_{3}$ concentration remaining below the detection limit (open circles).

increased slightly the mean diameter of nucleated particles, as well as their total number concentration (Fig. 3).

The above experiments show a clear, yet moderate, enhancing effect of ammonia on sulphuric acid-water nucleation. While this is qualitatively similar to what has been observed in other laboratory experiments (e.g., Ball et al., 1999; Benson et al., 2009), a quantitative comparison between these experiments, or between the experiments and available theories, is not possible at the moment. One reason for this is that the different experimental studies have been made at different $\mathrm{NH}_{3}$ and $\mathrm{H}_{2} \mathrm{SO}_{4}$ concentration levels. The second reason is that none of the laboratory experiments have been made at low (<tens of ppt) $\mathrm{NH}_{3}$ concentrations. This is crucial because nucleation rates predicted by the existing ternary $\mathrm{H}_{2} \mathrm{SO}_{4}-\mathrm{H}_{2} \mathrm{O}-\mathrm{NH}_{3}$ nucleation theories, although deviating quite a lot from each other, are most sensitive to changes in $\mathrm{NH}_{3}$ at concentration levels less than a few ppt (e.g., Napari et al., 2002, Anttila et al., 2005, Merikanto et al., 2007).

A series of experiments were conducted, in which tertbutylamine (as an arbitrary sample amine) instead of ammonia was added into the system (Berndt et al., 2010). Measurements at a relative humidity of $13 \%$ with a tertbutylamine addition of about $10^{10}$ molecules $\mathrm{cm}^{-3}$ showed an enhancement of produced particles by about two orders of magnitude, whereas extrapolation of the $\mathrm{NH}_{3}$ data down to concentrations of about $10^{10}$ molecules $\mathrm{cm}^{-3}$ suggested only a small or negligible effect of $\mathrm{NH}_{3}$. This finding indicates a very strong effect of amines for nucleation even for atmospheric amine concentrations in the range of $10^{8}$ $10^{9}$ molecule $\mathrm{cm}^{-3}$. Therefore, amines are probably promising candidates explaining existing discrepancies between binary nucleation theory and observations in the field and the laboratory. 


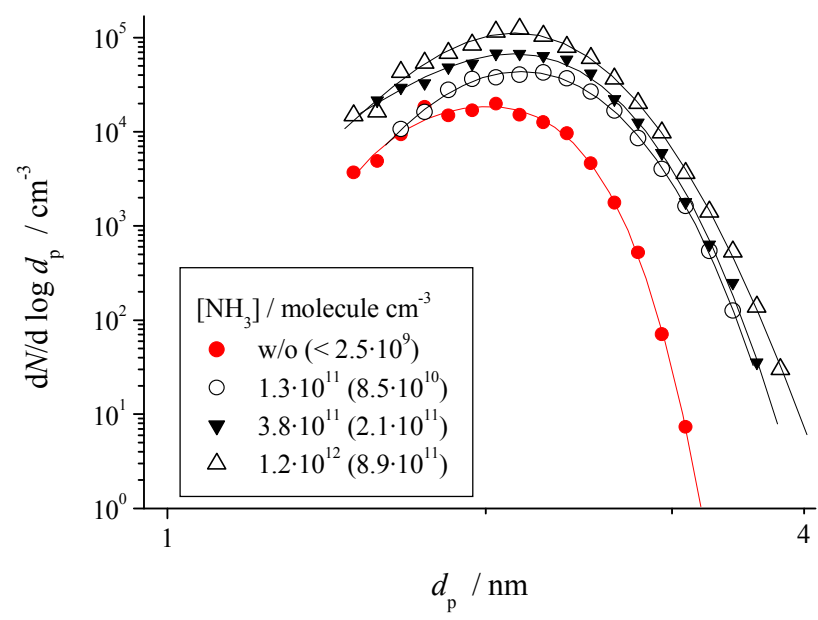

Fig. 3. Measured particle number size distributions over the size range of $1.5-4 \mathrm{~nm}$ in nucleation experiments conducted at different ammonia concentration levels. The $\mathrm{H}_{2} \mathrm{SO}_{4}$ concentration was $1.2 \times 10^{8}$ molecules $\mathrm{cm}^{-3}$ and the relative humidity was $22 \%$. The given $\mathrm{NH}_{3}$ concentrations refer to those inside the inlet and the corresponding outlet concentrations are presented in the brackets.

\subsection{Influence of organics}

The role of organic compounds in nucleation was investigated in Paul Scherrer Institute (PSI) by using an environmental chamber, and in Jülich using a Plant Aerosol Atmosphere Chamber (JPAC) setup.

A series of photo-oxidation experiments was performed in the $27-\mathrm{m}^{3}$ Paul Scherrer Institute environmental chamber investigating new particle formation in the presence of 1,3,5trimethylbenzene (TMB), $\mathrm{NO}_{\mathrm{x}}$ and $\mathrm{SO}_{2}$ at various mixing ratios (Metzger et al., 2010). After irradiation of this mixture $\mathrm{OH}$ radicals oxidized $\mathrm{SO}_{2}$ and TMB producing $\mathrm{H}_{2} \mathrm{SO}_{4}$ and a variety of organic products. The production of low volatility products lead to formation of secondary organic aerosols (SOA). The importance of sulphuric acid was clearly seen, as with increasing $\mathrm{SO}_{2}$ mixing ratio nucleation occurred earlier and the particle number concentration (diameter $>3 \mathrm{~nm}$ ) increased from $10^{3}$ to $10^{5} \mathrm{~cm}^{-3}$. After reaching the peak concentration, the particle number concentration decreased due to wall loss and coagulation.

Plotting the nucleation rate of 1.5 -nm particles $\left(J_{1.5}\right)$ versus the concentration of sulphuric acid yielded a slope close to 2 (Metzger et al., 2010). This would indicate that the critical cluster contains two sulphuric acid molecules. However, this only applies when other variables of influence (temperature and gas phase concentrations of other species participating in the nucleation process) remain constant. However, within an individual experiment $\mathrm{H}_{2} \mathrm{SO}_{4}$ and organic photooxidation products are expected to be highly correlated since their formation and loss processes are highly similar. For the further analysis, the concentration of a first order product of sufficiently low volatility to participate in the particle formation process (called NucOrg) was calculated based on the decay of the TMB concentration and assuming the same loss rates as sulphuric acid (for details see Metzger et al., 2010). The isopleth plot of Fig. 4 clearly shows that the data can only be explained with a dependence of the nucleation rate on both sulphuric acid and a nucleating organic (see Metzger et al., 2010, Supporting Information). Thus, the slope of 2 mentioned above is rather a result of highly correlated concentrations of sulphuric acid and NucOrg.

This result was also implemented in a global model. Parameterising this process in the global aerosol model GLOMAP resulted in substantially better agreement with ambient observations compared to control runs. It can therefore be speculated that in many locations, the new-particle formation is influenced not only by the sulphuric acid concentration but also by the concentrations of co-nucleating species. The chemical nature of these species remains, however, to be identified.

The JPAC setup at Jülich (Mentel et al., 2009) was used to study the effect of organics with realistic mixtures of organic emissions. The real plant emissions were introduced to air containing atmospheric levels of ozone, and the production of $\mathrm{OH}$ radicals was induced by the UV light. In experiments with a constant $\mathrm{OH}$ radical production rate and a varying organic vapour emission rate, it was found that both the mass and number production rates of $>5 \mathrm{~nm}$ particles increased with an increasing organic vapour source. For individual tree species, the emitted volatile carbon was the main predictor of formed aerosol number and mass, even though large variations between the different tree species were observed. Threshold concentrations of organic compounds initiating particle formation were lower for emissions from all the tree species than for the reference compound, $\alpha$-pinene. The differences between individual species could possibly be explained by oxidized VOC concentrations; sesquiterpenes were not found to play a specific role (Mentel et al., 2009). In another experiment series, plant emissions were studied in the presence and absence of added isoprene. From 3 to 4 $\mathrm{OH}$ radical reactions were needed to induce nucleation and the addition of isoprene suppressed aerosol number formation while having a negligible effect on particle growth. The suppression could be parameterised using a model that had particle number formation depending on the $\mathrm{OH}$ oxidation of other plant VOCs, with isoprene acting as an $\mathrm{OH}$ scavenger (Kiendler-Scharr et al., 2009).

In both JPAC experiments, a clear positive correlation between the amount of non-isoprene organic emissions and the rate of particle formation points towards an enhancing effect by organics. If particle formation was controlled by some inorganic vapour formed by $\mathrm{OH}$ oxidation, nucleation suppression by all $\mathrm{OH}$-reactive organics would be expected due to the competition for $\mathrm{OH}$ radicals. However, because the size cutoff in the measurements was significantly larger than the expected size of the newborn $\mathrm{CN}$, the exact nature of the 


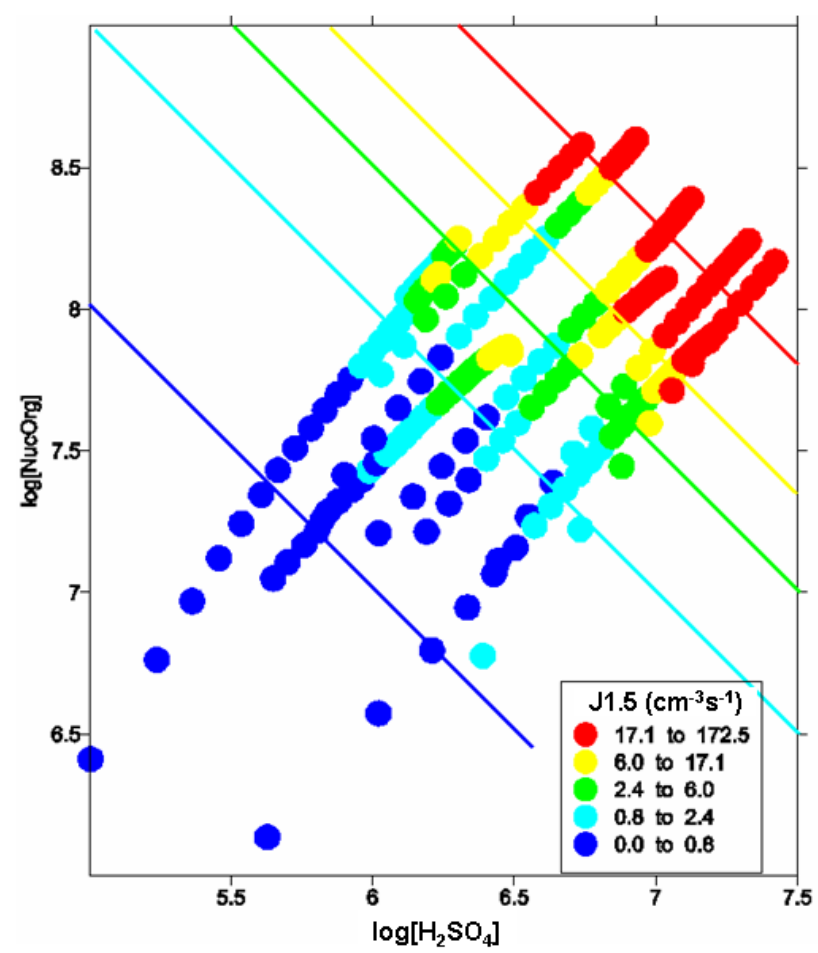

Fig. 4. Isopleth plot of $J_{1.5}\left(\mathrm{~cm}^{-3} \mathrm{~s}^{-1}\right)$ as a function of $\log \left[\mathrm{H}_{2} \mathrm{SO}_{4}\right]$ versus $\log [\mathrm{NucOrg}]$. The iso-lines are drawn to guide the eye. If $J_{1.5}$ depended on either $\mathrm{H}_{2} \mathrm{SO}_{4}$ or NucOrg alone the iso-lines would need to be horizontal or vertical, respectively. The diagonal iso-lines clearly show that the data can only be explained with a dependence of $J_{1.5}$ from both $\mathrm{H}_{2} \mathrm{SO}_{4}$ and NucOrg (from Metzger et al., 2010, Supporting Information).

formation enhancement mechanism remains unknown. The isoprene effect demonstrates that organics influence nucleation indirectly via effects on the gas phase oxidation; direct effects may include modifications of early growth or even participation in nucleation itself. Based on the JPAC measurements, particle formation is induced exclusively by (multiple) $\mathrm{OH}$ oxidation rather than ozonolysis of organic precursors.

\subsection{Heterogeneous nucleation experiments}

Laboratory experiments on the effect of charge (both negative and positive) on the heterogeneous nucleation probability were performed at University of Vienna (Winkler et al., 2008a). In those experiments, the condensing vapours used were $\mathrm{n}$-propanol, water and n-nonane, i.e. one water-soluble and one non-soluble organic substance. Both unary and binary nucleation were investigated.

An example of the conducted nucleation experiments can be seen in Fig. 5. This example illustrates clearly that when the saturation ratio of the vapour responsible for heterogeneous nucleation (here $n$-propanol) is gradually increased,

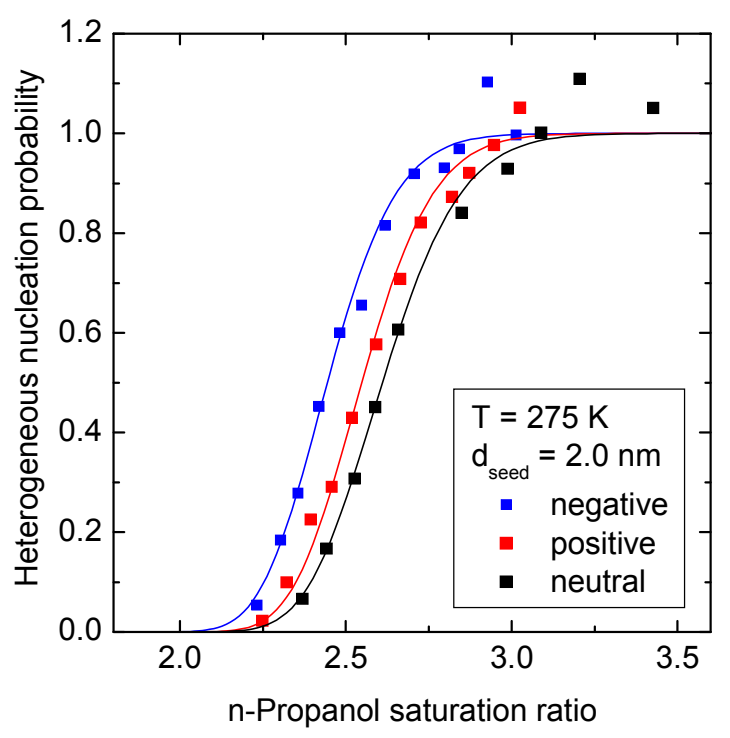

Fig. 5. Heterogeneous nucleation probability curves for the activation of differently charged tungsten oxide $\left(\mathrm{WO}_{\mathrm{x}}\right)$ particles with mean electrical mobility diameter of $2.0 \mathrm{~nm}$. Negatively charged particles are activated at lowest vapor saturation ratios followed by positively charged particles and neutral ones clearly indicating a charge and sign preference for the heterogeneous nucleation at this particle size.

the negatively-charged particles or clusters will activate first, then the positively-charged ones, and finally also the neutral ones. This kind of behaviour was evident in the sub- $4 \mathrm{~nm}$ size range, and the effect was more pronounced for smaller particle sizes (Winkler et al., 2008a).

Heterogeneous nucleation of clusters and particles can be described using the concept of activation (or nucleation) probability, $P$, which has been widely applied in the theory of heterogeneous nucleation (e.g., Lazaridis et al., 1992):

$P=\frac{N_{\text {acti }}}{N_{\mathrm{c}}}=1-\exp (-\mathrm{It})$,

Here $N_{\text {act }}$ is the number concentration of activated clusters (aerosol particles), $N_{\mathrm{c}}$ is the total cluster concentration before activation, $I$ is the heterogeneous nucleation rate (per aerosol particle and time), and $t$ is nucleation time. Activation of pre-existing clusters by sulphuric acid could explain the linear dependence of the nucleation rate to the sulphuric acid concentration (Kulmala et al., 2006), as seen in the recent laboratory experiments (Sects. 3.1 and 3.3) and many field observations (Sect. 5.3). Preferential activation of charged clusters over neutral ones might also explain the apparently larger contribution by ion-induced nucleation in the beginning of atmospheric nucleation events (see Sect. 4.2). 


\section{Field observations}

The specific feature of EUCAARI field measurements was the extensive use of various ion and cluster spectrometers. Prior to the EUCAARI Intensive Observation Period (IOP) that took place between March 2008 and April 2009, the Neutral cluster and Air Ion Spectrometer (NAIS; see Sect. 2.1) was operated intermittently in Hyytiälä, Finland (Kulmala et al., 2007a; Manninen et al., 2009a, b). During the IOP, five NAIS instruments and eight other ion spectrometers were continuously operated for roughly a full year at 13 field sites (Manninen et al., 2010). These sites included Hyytiälä and Pallas (Finland), Vavihill (Sweden), Mace Head (Ireland), Cabauw (The Netherlands), K-Puszta (Hungary), Hohenpeissenberg and Melpitz (Germany), San Pietro de Capofiume (Italy), Jungfraujoch (Schwitzerland), Puy de Dôme (France), Finokalia (Greece) and Marikana village (South Africa). Finally, free-tropospheric cluster measurements were conducted by operating the airborne NAIS in an aircraft during the EUCAARI LONGREX experiment in May 2008 (Mirme et al., 2010). In the following we summarise the main findings from the NAIS measurements, along with additional information obtained from the IonDMPS measurements.

\subsection{Detection of neutral and charged clusters and particles}

Prior to EUCAARI, experimental information on sub-3 nm atmospheric aerosol populations was based almost entirely on air ions, i.e. measuring charged molecular clusters and aerosol particles. The NAIS instrument made it possible to detect neutral atmospheric aerosol particles down to about $2 \mathrm{~nm}$ diameter. As a result, the first quantitative estimates on the concentrations of neutral sub-3 $\mathrm{nm}$ particles were obtained for both continental boundary layer (Kulmala et al., 2007a) and the free troposphere (Mirme et al., 2010).

Size distributions of neutral and naturally charged particles/clusters provide further insight into the origin and dynamics of nucleated particles. In practically all lowertropospheric environments, naturally charged particles were found to have an almost persistent and narrow concentration band, or mode, close to the mobility diameter of $1 \mathrm{~nm}$ (e.g. Hõrrak et al., 2003; Hirsikko et al., 2005; Vartiainen et al., 2007; Manninen et al., 2009a). The distinct presence of this cluster ion mode was perturbed only (i) by clouds, inside which the smallest ions are effectively scavenged by cloud droplets (Lihavainen et al., 2007; Venzac et al., 2007), (ii) by rain events that typically produced additional sub- $10 \mathrm{~nm}$ ions (see Tammet et al., 2009), and (iii) by some nucleation events (e.g. Hõrrak et al., 2003; Vana et al., 2008). The aircraft measurements made during the LONGREX experiment, along with ground-based measurements at high altitudes, revealed that the cluster ion mode can be seen in the free troposphere as well (Fig. 6; Venzac et al., 2007; Boulon

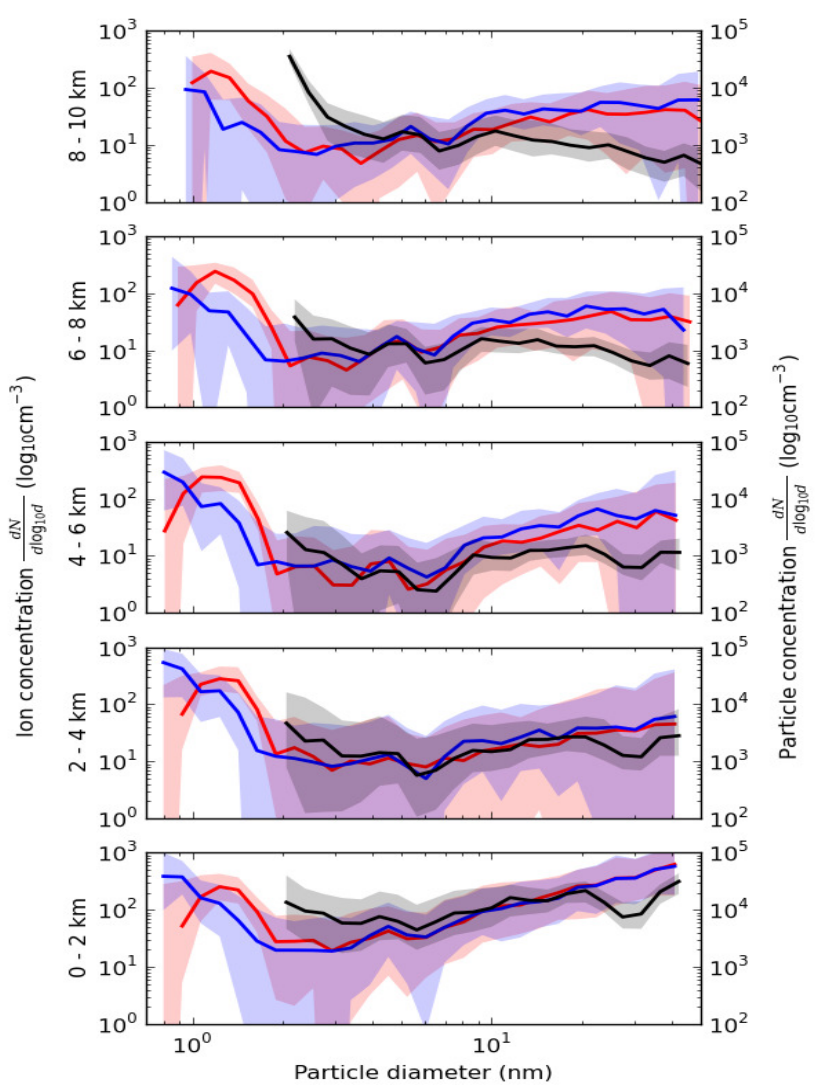

Fig. 6. Average particle (black) and ion (positive: red; negative: blue) number size distributions at different height levels during the EUCAARI LONGREX 2008 campaign. The shaded area represents variability (5 to 95 percentiles) of the corresponding number size distributions.

et al., 2010; Mirme et al., 2010). Concentrations of charged particles displayed usually a minimum just above the cluster ion mode and then a broader secondary maximum above $10 \mathrm{~nm}$ (e.g. Komppula et al., 2007). This latter mode results from the attachment of cluster ions with pre-existing neutral particles (see the simulations in Sect. 5.2), being most pronounced in polluted continental boundary layers loaded with Aitken mode particles (see Fig. 6).

Due to instrumental limitations, the NAIS cannot provide quantitative information about the total concentration of neutral sub-3 nm particles, nor about the exact shape of the corresponding size distribution down to $1 \mathrm{~nm}$. The existing NAIS data demonstrates, however, that neutral sub- $3 \mathrm{~nm}$ particles clearly dominate overcharged ones in the lower troposphere (Kulmala et al., 2007a; Manninen et al., 2009a). During the LONGREX measurements, concentrations of neutral particles in the diameter range 2-10 $\mathrm{nm}$ were, on average, roughly two orders of magnitude larger than those of charged particles throughout the tropospheric column (Fig. 6 and Mirme et al., 2010). 


\subsection{Contribution of ion-induced nucleation}

The NAIS and Ion-DMPS provide complementary information about the role of ion-induced nucleation in atmospheric new-particle formation. In Hyytiälä, Finland, these two instruments were operated in parallel for several months. An example of the resulting measurements during one of the nucleation event days is depicted in Fig. 7. Both instruments showed a clear increase in the charged fraction (CF) of 2.8$\mathrm{nm}$ particles at the beginning of the event, with subsequent decrease of the CF toward the end of the event. Such behaviour indicates that the contribution of the ion-induced nucleation to the total nucleation is at its highest during the initial stages of new-particle formation. Above $5 \mathrm{~nm}$, the value of the CF increased with increasing particle size, which can be explained by evolution of the nuclei toward charge equilibrium during their growth (Kerminen et al., 2007). The ratio of the apparent formation rate of charged particles to that of total particles is in line with these views (Fig. 7, bottom). The somewhat smaller values of the CF for the smallest particles recorded by the NAIS, as compared with the Ion-DMPS, are probably due to the background caused by charger ions inside the NAIS.

Both the NAIS and Ion-DMPS data indicate that ioninduced nucleation contributes, on average, less than $10 \%$ of the total nucleation rate in Hyytiälä (Gagné et al., 2008, 2010; Manninen et al., 2009b). However, the fraction of nucleation explained by ion-induced nucleation varied considerably between the different days, with larger fractions favoured by warmer and sunnier days. On most of the days, both neutral and ion-induced nucleation seemed to occur simultaneously, but with temporally varying portions (Laakso et al., 2007b; Gagné et al., 2010).

The multi-site operation of NAIS and other ion spectrometers (Manninen et al., 2010) revealed that the average formation rate of charged 2-nm particles $\left(0.1-0.2 \mathrm{~cm}^{-3} \mathrm{~s}^{-1}\right)$ varied surprisingly little between the different measurement sites, whereas the average total formation rate of 2-nm particles varied from below 1 to more than $30 \mathrm{~cm}^{-3} \mathrm{~s}^{-1}$. This indicates that neutral nucleation pathways become increasingly important when the total nucleation rate is higher. In more general terms, these results might be interpreted as a frequent, yet moderate, ion-induced nucleation taking place in the lower troposphere, outweighed by usually much stronger neutral nucleation that is sensitive to local atmospheric conditions.

According to theoretical arguments, the most favourable location for ion-induced nucleation is the upper part of the troposphere (Kazil et al., 2008; Yu, 2010). If the contribution of ion-induced nucleation to total nucleation were to increase considerably when going from the boundary layer toward the upper troposphere, one would expect to see a corresponding increase in the concentration ratio between charged and neutral clusters. During the air craft measurements conducted within the EUCAARI LONGREX campaign, no sign of such an increase was observed. More airborne measurements of charged and neutral sub- $3 \mathrm{~nm}$ clusters in different environments are clearly needed to address the role of ion-induced nucleation in free-tropospheric aerosol formation.

\section{Nucleation theory, modelling and parameterisations}

\subsection{Quantum chemical calculations}

Quantum chemical methods have become a powerful tool to study the molecular mechanism behind new-particle formation and composition of molecular clusters that are always present in the atmosphere (Kurtén and Vehkamäki, 2008; Nadykto et al., 2008). Most importantly, such a high-level theory can complement, guide and help to interpret experimental work, especially since experimental techniques detecting the composition of small molecular clusters present in the atmosphere are rapidly developing at the moment.

By using different quantum mechanics methods, atmospherically relevant molecular clusters were studied in EUCAARI, with the final aim of elucidating the molecular mechanism behind observed atmospheric nucleation. Quantum chemical calculations provide evaporation rates, or equivalently formation free energies, of different clusters that can be involved in nucleation. Evaporation rates are needed to assess the stability of various clusters and to identify the pathways through which clusters nucleate.

As part of EUCAARI, the evaporation rates of a wide variety of clusters were calculated, ranging from clusters containing only sulphuric acid to clusters containing complex molecules like amines or large organic acids (Fig. 8). Our main findings can be summarized as follows: (i) ammonia can enhance neutral sulphuric acid-water nucleation to some extent, but has a smaller role in corresponding ion-induced nucleation (Ortega et al., 2008), (ii) dimethylamine enhances neutral and ion-induced sulphuric acid-water nucleation in the atmosphere more effectively than ammonia (Kurtén et al., 2008; Loukonen et al., 2010), (iii) some of the organic acids resulting from monoterpene oxidiation can form very stable clusters with sulphuric acid, being good candidates to explain the pool of neutral clusters found in field measurements (see Sect. 4.1), and (iv) organo-sulphates can be involved in ion-induced nucleation. Note that indications of the presence of gaseous organo-sulfates ions were obtained, for the first time, by using the new APi-TOF instrument in EUCAARI (Sect. 2.4).

\subsection{Ion-UHMA}

A new modelling tool, called Ion-UHMA, which assists the interpretation of ion spectrometer measurements, was developed (Leppä et al., 2009). The Ion-UHMA is a sectional box model that simulates the dynamics of neutral and electrically charged aerosol particles under atmospheric conditions. It builds on the aerosol dynamical model UHMA (Korhonen et 

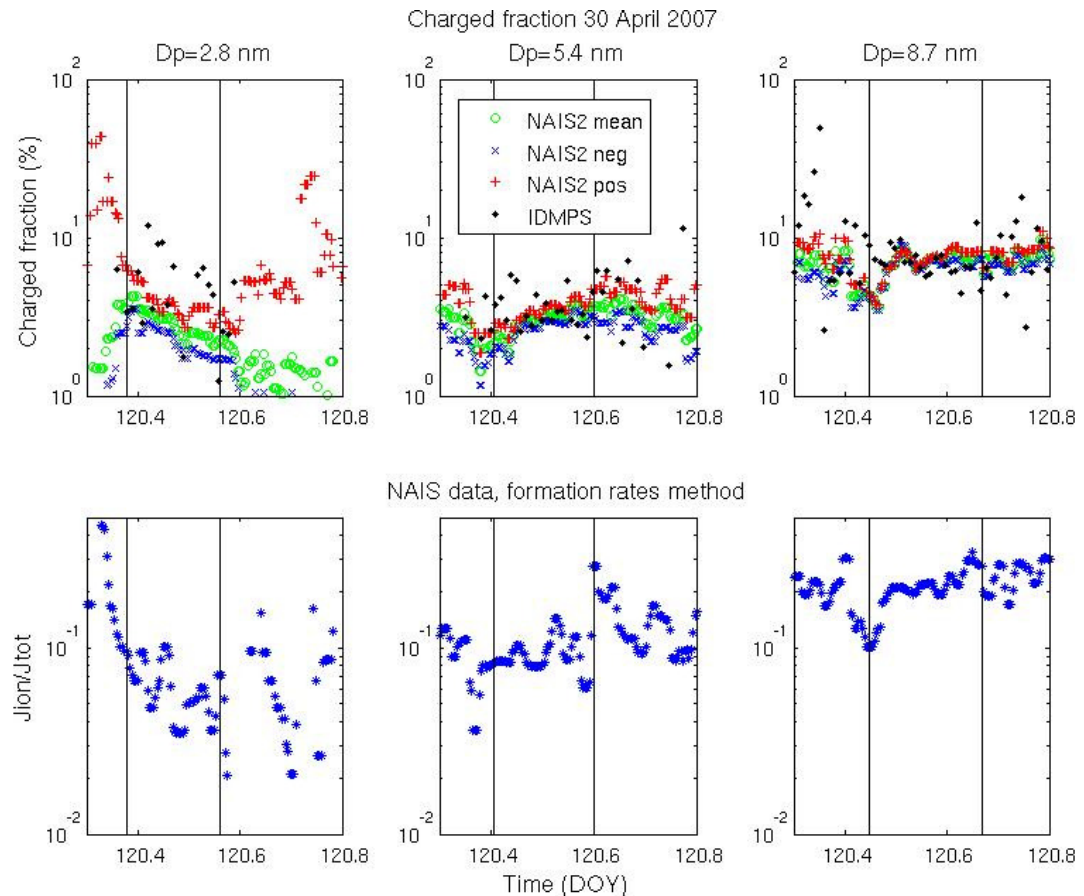

Fig. 7. Time evolution of the charged fraction of particles in three different size bins (top panels) based on NAIS and Ion-DMPS measurements at Hyytiälä on 30 April 2007. The lower panels depict the ratio between the charged and total particle production rate determined from the NAIS data at the corresponding size bins. The period during which the nucleation event effectively affects each size bin is separated by vertical bars in the figures.

al., 2004) and model AEROION (Laakso et al., 2002). The Ion-UHMA includes the basic aerosol dynamical processes (condensation, coagulation, dry deposition), along with ionaerosol attachment and ion-ion recombination. The formation of new aerosol particles is treated as an input to the model or, alternatively, the model can be coupled with an existing mechanistic nucleation model. The size range covered by the Ion-UHMA is adjustable, but typically ranges from $1-2 \mathrm{~nm}$ up to $1000 \mathrm{~nm}$.

The technical performance of the Ion-UHMA was tested, and its ability to simulate atmospheric nucleation events was evaluated (Leppä et al., 2009). Most importantly, it was shown that when the formation rates of neutral and charged $2 \mathrm{~nm}$ particles, as obtained from NAIS measurements (see Eqs. 1 and 2 in Sect. 2.1), are used as model inputs, the Ion-UHMA successfully reproduces the observed dynamics of both charged and neutral particles over the size range 2$20 \mathrm{~nm}$. This means that (i) the model correctly captures the aerosol dynamics taking place in this size range, and (ii) the formation rates of 2-nm particles determined from NAIS measurements are reliable.

As an example of Ion-UHMA simulations, we investigated how well it can reproduce the time evolution of particle number distribution measured in Hyytiälä on 15 April 2007. Measured values of temperature, relative humidity, formation rates of $2 \mathrm{~nm}$ particles, and concentrations of charged sub- $2 \mathrm{~nm}$ clusters and particles larger than $20 \mathrm{~nm}$ were used as model inputs. Averaged over the particle formation event, the measured formation rates of total, negative and positive particles were equal to $1.14,0.08$ and $0.09 \mathrm{~cm}^{-3} \mathrm{~s}^{-1}$, respectively, being indicative of the dominance of neutral nucleation. On the other hand, the fraction of 2-nm particles formed as charged was above the charging probability of particles of that size, so it is likely that ion-induced nucleation was operating as well during this day. Two condensing vapours were assumed in the simulation: sulphuric acid with a sinusoidal concentration pattern peaking at local noon (Petäjä et al., 2009), and an organic compound with a temporally constant and 1-2 orders of magnitude higher concentration than sulphuric acid. The exact concentration levels of these vapours were chosen such that the simulated growth rates of sub- $20 \mathrm{~nm}$ particles were close to observations.

The simulation produced a new particle formation event that was qualitatively similar to the measured one (Fig. 9). The formation of neutral particles dominated over that of charged particles, even though increased concentrations of charged particles at sizes of around 2-2.5 nm could be observed in both the simulation and measurements. These particles were formed as charged and their concentrations decreased with an increasing particle diameter due to their neutralization by ion-ion recombination. At sizes of around $4 \mathrm{~nm}$, concentrations of charged particles began to increase 


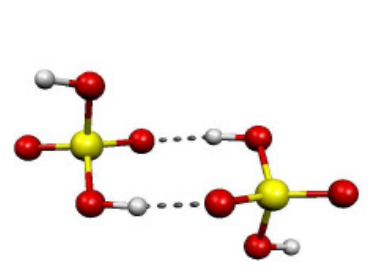

pure sulfuric acid $\mathrm{k}_{\text {evan }} \approx 10^{2} \ldots 10^{6} \mathrm{~s}^{-1}$

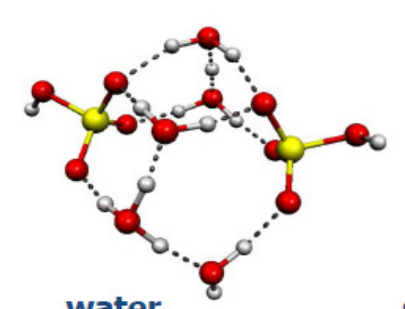

water small stabilization

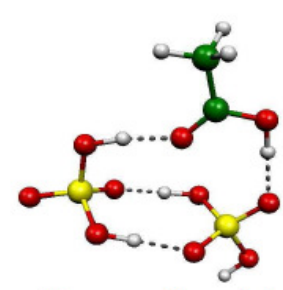

small organic acids no stabilization

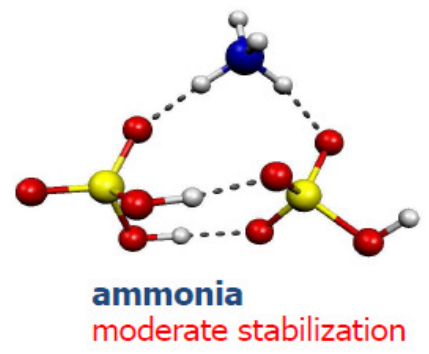

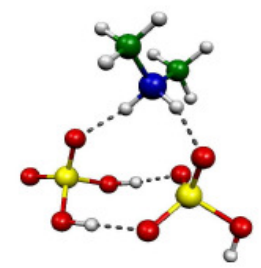

amines

large stabilization

Fig. 8. Relative stability of sulfuric acid clusters with different stabilizing compounds (water, organic acids, ammonia and dimethyl amine) based on the evaporation rates $k_{\text {evap }}$ calculated with quantum chemistry. The atoms are color-coded as follows: yellow - sulfur, red - oxygen, grey - hydrogen, blue - nitrogen and green - carbon. Dashed lines depict hydrogen bonds.

again due to the increasing efficiency of ion-aerosol attachment. The combined effect of these two phenomena was a concentration gap of charged particles at around 2-4 nm, observed both in the simulation and in the measurements. A gap in the number size distribution of charged particles below diameters of a few $\mathrm{nm}$ is frequently seen in association with measured new-particle formation events (e.g., Komppula et al., 2007; Suni et al., 2008; Vana et al., 2008; Manninen et al., 2009a).

While the overall evolution of the particle number size distribution was quite similar between the simulation and measurements, also some differences can be observed. For example, simulated concentrations of 10-20 nm particles were somewhat smaller than those observed. A probable reason for this is the slight underestimation of particle formation or growth rates from the measurement data. In this respect, the growth rates of the smallest particles are of specific importance, since these particles are most vulnerable to scavenging by coagulation into larger particles (Kerminen et al., 2004). Measurements at a fixed location are always affected by transport phenomena, including the diurnal evolution of the mixed layer height and advection of air masses with different aerosol characteristics. The former was apparently active prior to local noon, whereas the latter may have caused the minor but rapid change in the measured particle number size distribution between about 14:00 and 15:00 LT. Our box model is unable to imitate such transport phenomena.

In addition to assisting the interpretation of field measurements, ion-UHMA can be used for many other purposes. One such application is to estimate how accurately the growth rates of sub- $5 \mathrm{~nm}$ particles can be estimated from ion spectrometer measurement using the available methods (Hirsikko et al., 2005), and whether new methods to determine the formation and growth rates of freshly-nucleated particles from measurement data are needed.

\subsection{Nucleation rate parameterisations}

Over the years, nucleation parameterisations have been developed for binary $\mathrm{H}_{2} \mathrm{SO}_{4}-\mathrm{H}_{2} \mathrm{O}$ nucleation (Russell et al., 1994; Vehkamäki et al., 2002; $\mathrm{Yu}, 2008$ ), ternary $\mathrm{H}_{2} \mathrm{SO}_{4}$ $\mathrm{H}_{2} \mathrm{O}-\mathrm{NH}_{3}$ nucleation (Napari et al., 2002; Merikanto et al., 2007), and ion-induced nucleation (Turco et al., 1998; Modgil et al., 2005; Yu, 2010). While all these parameterisations reproduce quite accurately the nucleation rates predicted by corresponding nucleation theories, they all have problems when applied to large-scale atmospheric modelling. The existing binary $\mathrm{H}_{2} \mathrm{SO}_{4}-\mathrm{H}_{2} \mathrm{O}$ nucleation theories are not able to reproduce nucleation events observed in continental boundary layers (e.g., Spracklen et al., 2006; Jung et al., 2008; Chang et al., 2009), in addition to which they are not consistent with the most recent laboratory findings (see Sects. 3.1 and 3.3). Ternary $\mathrm{H}_{2} \mathrm{SO}_{4}-\mathrm{H}_{2} \mathrm{O}-\mathrm{NH}_{3}$ nucleation mechanisms may work reasonably well in sulphur-rich urban environments (Jung et al., 2008), but probably not in the global atmosphere (e.g., Lucas and Akimoto, 2004). In case of ioninduced nucleation the main problem is the scarcity of suitable measurement data, which so far has hindered the proper testing of this mechanism.

In EUCAARI, we concentrated on developing semiempirical nucleation parameterizations, in which the 
(a) Total, simulated

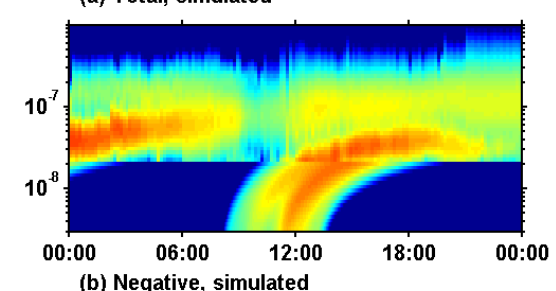

(b) Negative, simulated
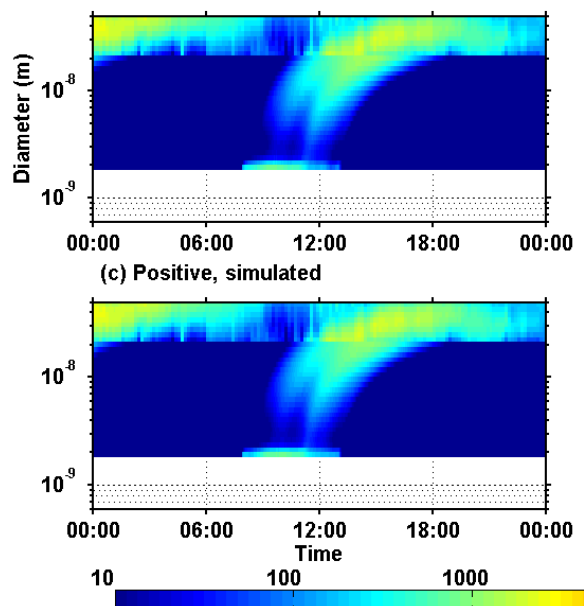

(d) Total, measured

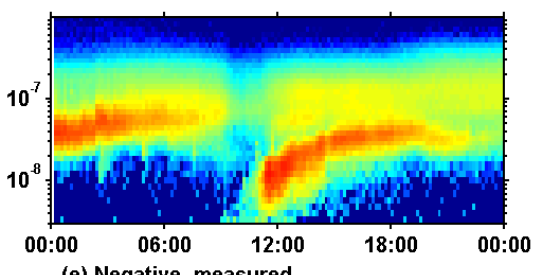

(e) Negative, measured
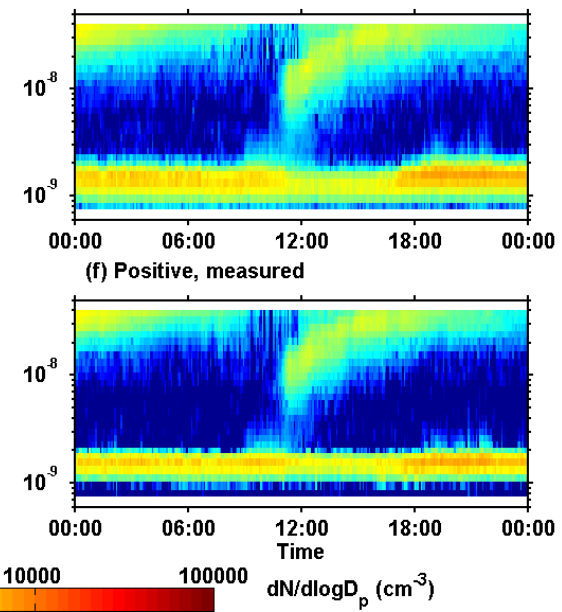

Fig. 9. Simulated (left panels) and measured (right panels) number size distribution of all particles (top row), negative ions (middle row) and positive ions (bottom row). The data represents the time evolution during a new particle formation event day (17 April 2007) in Hyytiälä, Finland.

nucleation rate is assumed to follow a simple power-law dependence on the gaseous sulphuric acid (and organic vapour) concentration. The reason for this is the accumulating evidence that such relations appear to mimic atmospheric nucleation much better than predictions based on classical nucleation theories (Sect. 3.1; Weber et al., 1996; Sihto et al., 2006; Riipinen et al., 2007; Kuang et al., 2008; Paasonen et al., 2009). By combining measurement data from four sites (Hyytiälä in Finland, Hohenpeissenberg and Melpitz in Germany, San Pietro Capofiume in Italy), the following eight candidate mechanisms were investigated (Paasonen et al., 2010):

$$
\begin{aligned}
& J_{2}=A\left[\mathrm{H}_{2} \mathrm{SO}_{4}\right], \\
& J_{2}=K\left[\mathrm{H}_{2} \mathrm{SO}_{4}\right]^{2}, \\
& J_{2}=A_{\mathrm{org}}[\mathrm{NucOrg}] \\
& J_{2}=K_{\mathrm{org}}[\mathrm{NucOrg}]^{2}, \\
& J_{2}=A_{\mathrm{s} 1}\left[\mathrm{H}_{2} \mathrm{SO}_{4}\right]+A_{\mathrm{s} 2}[\mathrm{NucOrg}], \\
& J_{2}=K_{\mathrm{het}}\left[\mathrm{H}_{2} \mathrm{SO}_{4}\right] \times[\mathrm{NucOrg}], \\
& J_{2}=K_{\mathrm{SA}_{1}}\left[\mathrm{H}_{2} \mathrm{SO}_{4}\right]^{2}+K_{\mathrm{SA}_{2}}\left[\mathrm{H}_{2} \mathrm{SO}_{4}\right] \times[\mathrm{NucOrg}],
\end{aligned}
$$

$$
\begin{aligned}
J_{2} & =K_{\mathrm{S} 1}\left[\mathrm{H}_{2} \mathrm{SO}_{4}\right]^{2}+K_{\mathrm{s} 2}\left[\mathrm{H}_{2} \mathrm{SO}_{4}\right] \times[\mathrm{NucOrg}] \\
& +K_{\mathrm{s} 3}[\mathrm{NucOrg}]^{2},
\end{aligned}
$$

Here, $J_{2}$ is the formation rate of 2-nm particles, [NucOrg] refers to the concentration of organic vapour(s) participating in nucleation, and $A_{i}$ and $K_{i}$ are the first and second order nucleation coefficients, respectively. At all the four sites, the $\mathrm{H}_{2} \mathrm{SO}_{4}$ concentration was obtained directly from measurements, whereas the organic vapour concentration was derived from the closure of $2-4 \mathrm{~nm}$ particle growth rates. The values of the coefficients $A_{i}$ and $K_{i}$ were determined for each site separately, as well as for the whole data set together, by fitting the regression formulae in question to the measurement data points. The success of the fittings was evaluated by looking at how well the measurement data points correlated with the fittings and how scattered they were with respect to the fitting.

The analysis showed that of the two mechanisms based solely on the $\mathrm{H}_{2} \mathrm{SO}_{4}$ concentration, Eq. (5) was clearly the better one and worked reasonably well for Hyytiälä, Melpitz and San Pietro Capofiume. However, the values of $K$ giving the best prediction for $J_{2}$ differed by more than a magnitude between these three sites. Neither Eq. (4) nor Eq. (5) worked for the Hohenpeissenberg data. Of the two mechanisms based solely on organic vapour concentrations, Eq. (7) was the best one in Hohenspeissenberg, whereas neither Eq. (6) 
nor Eq. (7) worked in the three other sites. The parameterisations relying on different combinations of $\mathrm{H}_{2} \mathrm{SO}_{4}$ and organic vapours (Eqs. 8-11) displayed a variable success between the four sites. When trying to predict the value of $J_{2}$ by using a single set of nucleation coefficient for all the sites together, Eqs. (10) and (11) appeared to work the best, even though none of the equations showed a superior performance over the others (Paasonen et al., 2010).

There are two issues worth mentioning here. First of all, the derivation of semi-empirical parameterizations, like Eqs. (4) to (11), is always subject to uncertainties in measured quantities. For example, there is up to $50 \%$ uncertainty in measured $\mathrm{H}_{2} \mathrm{SO}_{4}$ concentrations and even a slightly larger one in [NucOrg] due to uncertainties related to determining the growth rate of 2-4 nm particles (Paasonen et al., 2010). Likewise, formation rates of 2-nm particles $\left(J_{2}\right)$ may be up to a factor two lower or higher than the estimated ones due to uncertainties in measurements and data analysis (Manninen et al., 2010). Second, it is clear that Eqs. (4) to (11) are oversimplifications of the physical and chemical factors influencing the nucleation rate. These include the ambient temperature and relative humidity and the stabilizing effect of vapors other than $\mathrm{H}_{2} \mathrm{SO}_{4}$ and NucOrg, causing additional scatter in measured data points. Such factors need to be investigated more thoroughly in the future, along with the applicability of the current parameterizations for conditions other than the continental boundary layers.

All of the nucleation rate parameterisations presented above (Eqs. 4-11) are similar to the standard formalisms of chemical kinetics describing of second-order or pseudo-first order reactions of atmospheric gases and aerosols (Pöschl et al., 2007). Rate equations like Eqs. (10) and (11) are characteristic for processes that can proceed via different mechanistic pathways and can be described by a linear combination of the rates of each pathway. This approach is consistent with recent developments in the modelling of aerosol chemical transformation and aging by multi-component and multiphase processes (Shiraiwa et al., 2009, 2010). Equation (11) is the most general formulation and seems most promising as a basis for future developments aimed at a universally applicable parameterisation of aerosol nucleation rates across different regions and regimes.

Knowledge of both sulphuric acid and organic vapour concentrations appears necessary to explain and parameterise atmospheric nucleation rates, and the field measurements are in line with the most recent laboratory experiments discussed in Sects. 3.1 and 3.3. The strong interplay between sulphuric acid and low-volatile organics in atmospheric nucleation and subsequent particle growth is also apparent when looking at long-term changes in aerosol concentrations over Central Europe due to concomitant reductions in $\mathrm{SO}_{2}$ emissions (Hamed et al., 2010).

\subsection{Parameterising the apparent particle formation rate}

Direct application of nucleation rate parameterisations in large-scale models is not possible, or at least not desirable, for two reasons. First of all, most of the current global models simulating aerosol dynamics do not explicitly cover particle sizes relevant to nucleation. Second, the dynamics of freshly-nucleated particles depends in a complicated way on the interplay between their formation rate, their condensation growth and their scavenging by coagulation (Kerminen et al., 2004; McMurry et al., 2005; Pierce and Adams, 2007). Such interplay cannot be accurately handled in a large-scale modelling framework due to excessive computational costs.

For the reasons highlighted above, the early dynamics of nucleated clusters is usually parameterised in large-scale atmospheric models. In EUCAARI, a parameterisations that relates the formation rate of particles of diameter $d_{\mathrm{p}}\left(J\left(d_{\mathrm{p}}\right)\right.$, i.e. the apparent formation rate of particles at size $d_{\mathrm{p}}$ ) and the nucleation rate $\left(J_{\text {nuc }}\right)$ was derived (Lehtinen et al., 2007):

$J\left(d_{\mathrm{p}}\right)=J_{\mathrm{nuc}} \exp \left(\frac{d_{\mathrm{nuc}}}{m+1}\left[1-\left(\frac{d_{\mathrm{p}}}{d_{\mathrm{nuc}}}\right)^{m+1}\right] \frac{\operatorname{CoagS}\left(d_{\mathrm{nuc}}\right)}{\mathrm{GR}}\right)$.

Here $d_{\text {nuc }}$ is the size of nucleated clusters, $\operatorname{CoagS}\left(d_{\text {nuc }}\right)$ is their coagulation sink, i.e. the rate at which they coagulate with pre-existing aerosol particles, GR is their growth rate, and $m(\sim 1.5-2)$ is a constant that depends on the shape of the particle number size distribution. Predictions by Eq. (12) are similar to those by the widely-applied formulae proposed by Kerminen and Kulmala (2002).

A drawback of Eq. (12), like in all other corresponding parameterisations developed until now, is the neglect of nuclei self-coagulation. This process accelerates nuclei growth and reduces their number concentration. Anttila et al. (2010) derived an iterative procedure by which the effect of nuclei self-coagulation on GR and CoagS can be taken into account when applying Eq. (12). Comparisons to detailed numerical simulations showed that the apparent particle formation rate is affected by nuclei self-coagulation only when atmospheric nucleation rates are exceptionally high $\left(>10 \mathrm{~cm}^{-3} \mathrm{~s}^{-1}\right.$ in the free troposphere and $>10^{4} \mathrm{~cm}^{-3} \mathrm{~s}^{-1}$ in the polluted boundary layer).

In order to apply the parameterisations by Lehtinen et al. (2007) and Anttila et al. (2010) in atmospheric models, the following quantities need to be known or derived from other model variables: (i) the nucleation rate, (ii) the particle number size distribution, and (iii) the concentrations of vapours that cause the fresh nuclei to grow in size. The first of these requirements means simply that the aerosol formation rate parameterisation cannot be used without a nucleation rate parameterisation. The second one implies that the representation of the particle size distribution in the model must allow for determination of the coagulation sink. The third requirement is perhaps the toughest one: the model needs to have some way of estimating the sulphuric acid concentration or, 
preferably, concentrations of all the vapours that contribute significantly to the nuclei growth. Potential ways to deal with condensing vapour concentrations in a large-scale modelling framework have been discussed lately by Chang et al. (2009).

\section{Concluding remarks}

Our understanding of atmospheric nucleation relies essentially on four very different sources of information: field measurements, laboratory experiments, theoretical calculations and model studies. Until very recently, these approaches have not been able to provide a consistent picture on atmospheric nucleation. Perhaps the most important problem in this regard has been the relation between the nucleation rate and the identity and concentrations of nucleating vapours. For example, the functional dependence of the nucleation rate on the gaseous sulphuric acid concentration, as observed in the ambient atmosphere, appeared very different from that seen in most laboratory experiments, and neither field nor laboratory data could be reconciled with existing classical nucleation theories.

As demonstrated in this publication, the EUCAARI project has significantly reduced the gap between the different approaches used to tackle atmospheric nucleation. The most important reason for this development has been the enhanced capabilities to measure sub- $3 \mathrm{~nm}$ particle populations, along with the extensive application of the new instruments in both laboratory and field. From a theoretical point of view, quantum chemical calculations have eventually evolved to a stage, at which they can provide useful information to guide measurements and to constrain model approaches.

All the results obtained during EUCAARI indicate that sulphuric acid plays a central role in atmospheric nucleation. However, our most recent laboratory experiments and field measurements show that also vapours other than sulphuric acid are needed to explain the nucleation process. Such vapours might be of organic origin, at least in continental boundary layers. By stabilizing molecular clusters containing sulphuric acid, it has been speculated for quite some time that basic vapours like ammonia would participate in atmospheric nucleation. The laboratory experiments and quantum chemical calculations made within EUCAARI give support for the moderate involvement of ammonia in nucleation, and indicate further that amines might be even more important than ammonia in assisting atmospheric nucleation.

The field and laboratory data obtained during EUCAARI demonstrate that the nucleation rate scales to the first or second power of the nucleating vapour concentration(s). This agrees with the few earlier field observations, but is in stark contrast with classical thermodynamic nucleation theories, such as binary sulphuric acid-water nucleation or ternary sulphuric acid-water-ammonia nucleation. The new findings, while suggesting that the formation of very small molecu- lar clusters drives atmospheric nucleation, are not sufficient enough to reveal the actual nucleation mechanism.

The EUCAARI field measurements brought plenty of new insight into the role of ions in atmospheric nucleation. One important finding was that the average formation rate of charged 2-nm particles varied very little, by roughly a factor two, between the different measurement sites. This contrasts to the average total formation rate of 2-nm particles which varied by almost two orders of magnitude between the sites. The contribution of charged particles to the total formation rate of 2-nm particles was usually well below $10 \%$, but it showed substantial temporal variability both during a nucleation event and between the different event days. In general, our observations are indicative of frequent, yet moderate, ion-induced nucleation usually outweighed by much stronger neutral nucleation in the continental lower troposphere. No evidence on the enhanced role of ion-induced nucleation in the upper free troposphere, as suggested by some theoretical studies, was obtained from our air craft measurements.

The most concrete outcome of the EUCAARI nucleation studies are the new semi-empirical nucleation rate parameterisations, along with updated aerosol formation parameterisations. Although these parameterisations require theoretical improvements, as well as intensive testing against both laboratory and field data, we recommend that they should gradually replace the traditional binary and ternary nucleation parameterisations currently used in most atmospheric models. From a global and Earth System modelling point of view, the new semi-empirical nucleation parameterisations provide a simple and effective tool, by which one can investigate the sensitivity of the global aerosol system to atmospheric nucleation and related emissions of precursor gases and primary particles.

Several open questions remain that should be addressed in the future. First of all, we do not really know whether atmospheric nucleation is dominated by a single nucleation pathway, or whether multiple different mechanisms are competing with each other. Second, the relative importance of the kinetic and thermodynamic factors controlling the nucleation rate is unclear. Third, the identity and role of organic vapours in the nucleation process are still unknown. Finally, although ion-induced nucleation appears to be of minor significance in continental boundary layers, this is not necessarily the case in the free troposphere or above the oceans. In this regard, there are very little experimental data on how ions interact with neutral particles and clusters in the sub- $2 \mathrm{~nm}$ size range.

In order to address the remaining knowledge gaps and to quantify the relevant nucleation mechanisms, we need to find out how the actual nucleation rate is connected with the dynamics of the smallest atmospheric clusters. This requires information on the chemical composition, physical properties and evaporation rates of these clusters. Essential tools to tackle the problem are highly sensitive and selective new instruments capable of operating at the sub$2 \mathrm{~nm}$ size range, kinetic molecular-scale models, laboratory 
experiments, and various theoretical approaches relying on both quantum chemistry and classical thermodynamics.

Acknowledgements. This work has been supported by European Commission 6th Framework program projects EUCAARI (contract no. 036833-2) and EUSAAR (contract no. 026140). The support from the Academy of Finland Centre of Excellence program (project no. 211483, 211484 and 1118615) is also gratefully acknowledged.

Edited by: E. Swietlicki

\section{References}

Aalto, P. P., Hämeri, K., Becker, E., Weber, R., Salm, J., Mäkelä, J. M., Hoell, C., O’Dowd, C. D., Karlsson, H., Hansson, H.-C., Väkevä, M., Koponen, I. K., Buzorius, G., and Kulmala, M.: Physical characterization of aerosol particles during nucleation events, Tellus B, 53, 344-358, 2001.

Anttila, T., Vehkamäki, H., Napari, I., and Kulmala, M.: Effect of ammonium bisulphate formation on atmospheric water-sulphuric acid-ammonia nucleation, Boreal Environ. Res., 10, 511-523, 2005.

Anttila, T., Kerminen, V.-M., and Lehtinen, K. E. J.: Parameterizing the formation rate of new particles: the effect of nuclei self-coagulation, J. Aerosol Sci., 41, 621-636, 2010.

Asmi, E., Sipilä, M., Manninen, H. E., Vanhanen, J., Lehtipalo, K., Gagné, S., Neitola, K., Mirme, A., Mirme, S., Tamm, E., Uin, J., Komsaare, K., Attoui, M., and Kulmala, M.: Results of the first air ion spectrometer calibration and intercomparison workshop, Atmos. Chem. Phys., 9, 141-154, doi:10.5194/acp-9-141-2009, 2009.

Ball, S. M., Hanson, D. R., Eisele, F., and McMurry, P. H.: Laboratory studies of particle nucleation: Initial results for than $\mathrm{H}_{2} \mathrm{SO}_{4}$, $\mathrm{H}_{2} \mathrm{O}$, and $\mathrm{NH}_{3}$ vapors, J. Geophys. Res., 104, 23709-23718, 1999.

Benson, D. R., Young, L.-H., Kameel, F. R., and Lee, S.-H.: Laboratory-measured nucleation rates of sulfuric acid and water binary homogeneous nucleation from the $\mathrm{SO}_{2}+\mathrm{OH}$ reaction, Geophys. Res. Lett., 35, L11801, doi:10.1029/2008GL033387, 2008.

Berndt, T., Böge, O., Stratmann, F., Heintzenberg, J., Kulmala, M.: Rapid formation of sulfuric acid particles at near-atmospheric conditions, Science, 307, 698-700, 2005.

Berndt, T., Stratmann, F., Bräsel, S., Heintzenberg, J., Laaksonen, A., and Kulmala, M.: $\mathrm{SO}_{2}$ oxidation products other than $\mathrm{H}_{2} \mathrm{SO}_{4}$ as a trigger of new particle formation. Part 1: Laboratory investigations, Atmos. Chem. Phys., 8, 6365-6374, doi:10.5194/acp8-6365-2008, 2008.

Berndt, T., Stratmann, F., Sipilä, M., Vanhanen, J., Petäjä, T., Mikkil, J., Grüner, A., Spindler, G., Lee Mauldin III, R., Curtius, J., Kulmala, M., and Heintzenberg, J.: Laboratory study on new particle formation from the reaction $\mathrm{OH}+\mathrm{SO}_{2}$ : influence of experimental conditions, $\mathrm{H}_{2} \mathrm{O}$ vapour, $\mathrm{NH}_{3}$ and the amine tert-butylamine on the overall process, Atmos. Chem. Phys., 10, 7101-7116, doi:10.5194/acp-10-7101-2010, 2010.

Bowman, A. F., Lee, D. S., Asman, W. A. H., Dentener, F. J., Van Der Hoek, K. W., and Olivier, J. G. J.: A global high-resolution emission inventory for ammonia, Global Biogeochem. Cy., 11, 5761-5787, 1997.

Boulon, J., Sellegri, K., Venzac, H., Picard, D., Weingartner, E., Wehrle, G., Collaud Coen, M., Bütikofer, R., Flückiger, E., Baltensperger, U., and Laj, P.: New particle formation and ultrafine charged aerosol climatology at a high altitude site in the Alps (Jungfraujoch, $3580 \mathrm{~m}$ a.s.l., Switzerland), Atmos. Chem. Phys., 10, 9333-9349, doi:10.5194/acp-10-9333-2010, 2010.

Chang, L.-S., Schwartz, S. E., McGraw, R., and Lewis, E. R.: Sensitivity of aerosol properties to new particle formation mechanism and to primary emissions in a continentalscale chemical transport model, J. Geophys. Res., 114, D07203, doi:10.1029/2008JD011019, 2009.

Clayes, M., Iinuma, Y., Szmigielski, R., Surratt, J. D., Blockhuys, F., Van Alsenoy, C., Böge, O., Sierau, B., Gomez-Gonzalez, Y., Vermeylen, R., Van der Veken, P., Shahgholi, M., Chan, A. W. H., Herrmann, H., Seinfeld, J. H., and Maenhaut, W.: Terpenylic acid and related compounds from the oxidation of $\alpha$-pinene: Implications for new particle formation and growth above forest, Environ. Sci. Technol., 43, 6976-6982, 2009.

Ehn, M., Junninen, H., Petäjä, T., Kurtén, T., Kerminen, V.-M., Schobesberger, S., Manninen, H. E., Ortega, I. K., Vehkamki, H., Kulmala, M., and Worsnop, D. R.: Composition and temporal behavior of ambient ions in the boreal forest, Atmos. Chem. Phys., 10, 8513-8530, doi:10.5194/acp-10-8513-2010, 2010.

Eichkorn, S., Wilhelm, S., Aufmhoff, H., Wohlfrom, K. H., and Arnold, F.: Cosmic ray-induced aerosol-formation: First observational evidence from aircraft-based ion mass spectrometer measurements in the upper troposphere, Geophys. Res. Lett., 29(14), 1698, doi:10.1029/2002GL015044, 2002.

Eisele, F. L.: Natural and anthropogenic negative ions in the troposphere, J. Geophys. Res., 94, 2183-2196, 1989a.

Eisele, F. L.: Natural and transmission line produced positive ions, J. Geophys. Res., 94, 6309-6318, 1989b.

Gagné, S., Laakso, L., Petäjä, T., Kerminen, V.-M., and Kulmala, M.: Analysis of one year of Ion-DMPS data from the SMEAR II station, Finland, Tellus B, 60, 318-329, 2008.

Gagné, S., Nieminen, T., Kurtén, T., Manninen, H. E., Petäjä, T., Laakso, L., Kerminen, V.-M., Boy, M., and Kulmala, M.: Factors influencing the contribution of ion-induced nucleation in a boreal forest, Finland, Atmos. Chem. Phys., 10, 3743-3757, doi:10.5194/acp-10-3743-2010, 2010.

Hamed, A., Birmili, W., Joutsensaari, J., Mikkonen, S., Asmi, A., Wehner, B., Spindler, G., Jaatinen, A., Wiedensohler, A., Korhonen, H., Lehtinen, K. E. J., and Laaksonen, A.: Changes in the production rate of secondary aerosol particles in Central Europe in view of decreasing $\mathrm{SO}_{2}$ emissions between 1996 and 2006, Atmos. Chem. Phys., 10, 1071-1091, doi:10.5194/acp-10-10712010, 2010.

Hering, S. V., Stolzenburg, M. R., Quant, F. R., Oberreit, D. R., and Keady, P. B.: A laminar-flow, water-based condensation particle counter (WCPC), Aerosol Sci. Technol., 39, 428-436, 2005.

Hermann, M., Wehner, B., Bischof, O., Han, H.-S., Krinke, T., Liu, W., Zerrath, A., and Wiedensohler, A.: Particle counting efficiencies of new TSI condensation particle counters, J. Aerosol Sci., 38, 674-682, 2007.

Herrmann, W., Eichler, T., Bernardo, N., and de la Mora, J. F.: Turbulent transition arises at Re 35000 in a short Vienna type DMA with a large laminarizing inlet, Abstract to the annual conference 
of the AAAR, St. Louis, MO, 6-10 October, 2000.

Hirsikko, A., Laakso, L., Hõrrak, U., Aalto, P. P., Kerminen, V.M., and Kulmala, M: Annual and size dependent variation of growth rates and ion concentrations in boreal forest, Boreal Environ. Res., 10, 357-369, 2005.

Hoppel, W. A.: Determination of the aerosol size distribution from the mobility distribution of the charged fraction of aerosols, J. Aerosol Sci., 9, 41-54, 1978.

Hõrrak, U., Salm, J., and Tammet, H.: Diurnal variation in the concentration of air ions of different mobility class in a rural area, $\mathrm{J}$. Geophys. Res., 108, 4653, doi:10.1029/2002JD003240, 2003.

Iida, K., Stolzenburg M., McMurry, P., Dunn, M. J., Smith, J. N. Eisele, F., and Keady, P.: Contribution of ion-induced nucleation to new particle formation: Methodology and its application to atmospheric observations in Boulder, Colorado, J. Geophys. Res., 111, D23201, doi:10.1029/2006JD007167, 2006.

Iida, K., Stolzenburg, M. R., and McMurry, P. H.: Effect of working fluid on sub-2nm particle detection with a laminar flow ultrafine condensation particle counter, Aerosol Sci. Tech., 43, 81-96, 2009.

Jung, J. G., Pandis, S. N., and Adams, P. J.: Evaluation of nucleation theories in a sulfur-rich environment, Aerosol Sci. Tech., 42, 495-504, 2008.

Junninen, H., Ehn, M., Petäjä, T., Luosujärvi, L., Kotiaho, T., Kostiainen, R., Rohner, U., Gonin, M., Fuhrer, K., Kulmala, M., and Worsnop, D. R.: A high-resolution mass spectrometer to measure atmospheric ion composition, Atmos. Meas. Tech., 3, 10391053, doi:10.5194/amt-3-1039-2010, 2010.

Kazil, J., Harrison, R. G., and Lovejoy, E. R.: Tropospheric new particle formation and the role of ions, Space Sci. Rev., 137, 241255,2008

Kazil, J., Stier, P., Zhang, K., Quaas, J., Kinne, S., O’Donnell, D., Rast, S., Esch, M., Ferrachat, S., Lohmann, U., and Feichter, J.: Aerosol nucleation and its role for clouds and Earth's radiative forcing in the aerosol-climate model ECHAM5-HAM, Atmos. Chem. Phys. Discuss., 10, 12261-12308, doi:10.5194/acpd-1012261-2010, 2010

Kerminen, V.-M. and Kulmala, M.: Analytical formulae connecting the "real" and the "apparent" nucleation rate and the nuclei number concentration for atmospheric nucleation events, J. Aerosol Sci., 33, 609-622, 2002.

Kerminen, V.-M., Lehtinen, K. E. J., Anttila, T., and Kulmala, M.: Dynamics of atmospheric nucleation mode particles: A time scale analysis, Tellus B, 56, 135-146, 2004.

Kerminen, V.-M., Lihavainen, H., Komppula, M., Viisanen, Y., and Kulmala, M.: Direct observational evidence linking atmospheric aerosol formation and cloud droplet activation, Geophys. Res. Lett., 32, L14803, doi:10.1029/2005GL023130, 2005.

Kerminen, V.-M., Anttila, T., Petäjä, T., Laakso, L., Gagné, S., Lehtinen, K. E. J., and Kulmala, M.: Charging state of the atmospheric nucleation mode: implications for separating neutral and ion-induced nucleation, J. Geophys. Res., 112, D21205, doi:10.1029/2007JD008649, 2007.

Kiendler-Scharr, A., Wildt, J., Dal Maso, M., Hohaus, T., Kleist, E., Mentel, T. F., Tillmann, R., Uerlings, R., Schurr, U., and Wahner A.: Isoprene emissions inhibit new particle formation in forests, Nature, 461, 381-384, doi:10.1038/nature08292, 2009.

Komppula, M., Vana, M., Kerminen, V.-M., Lihavainen, H., Viisanen, Y., Hõrrak, U., Komsaare, K., Tamm, E., Hirsikko, A.,
Laakso, L., and Kulmala, M.: Size distributions of atmospheric ions in the Baltic Sea region, Boreal Environ. Res., 12, 323-336, 2007.

Korhonen, H., Lehtinen, K. E. J., and Kulmala, M.: Multicomponent aerosol dynamics model UHMA: model development and validation, Atmos. Chem. Phys., 4, 757-771, doi:10.5194/acp-4757-2004, 2004.

Kuang, C., McMurry, P. H., McCormick, A. V., and Eisele, F., L.: Dependence of nucleation rates on sulfuric acid vapor concentration in diverse atmospheric locations, J. Geophys. Res., 113, D10209, doi:10.1029/2007JD009253, 2008.

Kulmala, M. and Kerminen, V.-M.: On the formation and growth of atmospheric nanoparticles, Atmos. Res., 90, 132-150, 2008.

Kulmala, M., Vehkamäki, H., Petäjä, T., Dal Maso, M., Lauri, A., Kerminen, V.-M., Birmili, W., and McMurry, P. H.: Formation and growth rates of ultrafine atmospheric particles: A review of observations, J. Aerosol Sci., 35, 143-176, 2004.

Kulmala, M., Lehtinen, K. E. J., Laakso, L., Mordas, G., and Hämeri, K.: On the existence of neutral atmospheric clusters, Boreal Environ. Res., 10, 79-87, 2005.

Kulmala, M., Lehtinen, K. E. J., and Laaksonen, A.: Cluster activation theory as an explanation of the linear dependence between formation rate of $3 \mathrm{~nm}$ particles and sulphuric acid concentration, Atmos. Chem. Phys., 6, 787-793, doi:10.5194/acp-6-787-2006, 2006.

Kulmala, M. , Riipinen, I., Sipilä, M., Manninen, H. E., Petäjä, T., Junninen, H., Dal Maso, M., Mordas, G., Mirme, A., Vana., M., Hirsikko, A., Laakso, L., Harrison, R. M., Hanson, I., Leung, C., Lehtinen, K. E. J., and Kerminen, V.-M.: Towards direct measurements of atmospheric nucleation, Science, 318, 89-92, 2007a.

Kulmala, M., Mordas, G., Petäjä, T., Grönholm, T., Aalto, P. P., Vehkamäki, H., Hienola, A. I, Herrmann, E., Sipilä, M., Riipinen, I., Manninen, H. E., Hämeri, K., Stratman, F., Bilde, M., Winkler, P. M., Wolfram, B., and Wagner, P. E.: The Condensation Particle Counter Battery (CPCB): A new tool to investigate the activation properties of nanoparticles, J. Aerosol Sci., 38, 289-304, 2007b.

Kulmala, M., Asmi, A., Lappalainen, H. K., Carslaw, K. S., Pöschl, U., Baltensperger, U., Hov, Ø., Brenquier, J.-L., Pandis, S. N., Facchini, M. C., Hansson, H.-C., Wiedensohler, A., and O'Dowd, C. D.: Introduction: European Integrated Project on Aerosol Cloud Climate and Air Quality interactions (EUCAARI) - integrating aerosol research from nano to global scales, Atmos. Chem. Phys., 9, 2825-2841, doi:10.5194/acp-9-2825-2009, 2009.

Kurtén, T. and Vehkamäki, H.: Investigating atmospheric sulfuric acid-water-ammonia particle formation using quantum chemistry, Adv. Quantum Chem., 55, 407-427, 2008.

Kurtén, T., Loukonen, V., Vehkamäki, H., and Kulmala, M.: Amines are likely to enhance neutral and ion-induced sulfuric acid-water nucleation in the atmosphere more effectively than ammonia, Atmos. Chem. Phys., 8, 4095-4103, doi:10.5194/acp8-4095-2008, 2008.

Kuwata, M., Kondo, Y., Miyazaki, Y., Komazaki, Y., Kim, J. H., Yum, S. S., Tanimoto, H., and Matsueda, H.: Cloud condensation nuclei activity at Jeju Island, Korea in spring 2005, Atmos. Chem. Phys., 8, 2933-2948, doi:10.5194/acp-8-2933-2008, 2008. 
Laakso, L., Mäkelä, J. M., Pirjola, L., and Kulmala, M.: Model studies on ion-induced nucleation in the atmosphere, J. Geophys. Res., 107(D20), 4427, doi:10.1029/2002JD002140, 2002.

Laakso, L., Gagné, S., Petäjä, T., Hirsikko, A., Aalto, P. P., Kulmala, M., and Kerminen, V.-M.: Detecting charging state of ultra-fine particles: instrumental development and ambient measurements, Atmos. Chem. Phys., 7, 1333-1345, doi:10.5194/acp-7-13332007, 2007a.

Laakso, L., Grönholm, T., Kulmala, L., Haapanala, S., Hirsikko, A., Lovejoy, E. R., Kazil, J., Kurtén, T., Boy, M., Nilsson, E. D., Sogachev, A., Riipinen, I., Stratmann, F., and Kulmala, M.: Hotair balloon as a platform for boundary layer profile measurements during particle formation, Boreal Environ. Res., 12, 279-294, 2007b.

Laaksonen, A., Hamed, A., Joutsensaari, J., Hiltunen, L., Cavalli, F., Junkermann, W., Asmi, A., Fuzzi, S., Facchini, M. C.: Cloud condensation nuclei production from nucleation events at a highly polluted region, Geophys. Res. Lett., 32, L06812, doi:10.1029/2004GL022092, 2005.

Lazaridis, M., Kulmala, M., and Gorbunov, B. Z.: Binary heterogeneous nucleation at a non-uniform surface, J. Aerosol Sci., 23, 457-466, 1992.

Lehtinen, K. E. J., Dal Maso, M., Kulmala, M., and Kerminen, V.M.: Estimating nucleation rates from apparent particle formation rates and vice versa: Revised formulation of the KerminenKulmala equation, J. Aerosol Sci., 38, 988-994, 2007.

Lehtipalo, K., Sipilä, M., Riipinen, I., Nieminen, T., and Kulmala, M.: Analysis of atmospheric neutral and charged molecular clusters in boreal forest using pulse-height CPC, Atmos. Chem. Phys., 9, 4177-4184, doi:10.5194/acp-9-4177-2009, 2009.

Leppä, J., Kerminen, V.-M., Laakso, L., Korhonen, H., Lehtinen, K. E. J., Gagne, S., Manninen, H. E., Nieminen, T., and Kulmala, M.: Ion-UHMA: a model for simulating the dynamics of neutral and charged aerosol particles, Boreal Environ. Res., 14, 559$575,2009$.

Lihavainen, H., Kerminen, V.-M., Komppula, M., Hatakka, J., Aaltonen, V., Kulmala, M., and Viisanen, Y.: Production of "potential" cloud condensation nuclei associated with atmospheric new-particle formation in northern Finland, J. Geophys. Res., 108(D24), 4782, doi:10.1029/2003JD003887, 2003.

Lihavainen, H., Komppula, M., Kerminen, V.-M., Järvinen, H., Viisanen Y., Lehtinen, K., Vana, M., and Kulmala, M.: Size distributions of atmospheric ions inside clouds and in cloud-free air at a remote continental site, Boreal Environ. Res., 12, 337-344, 2007.

Loukonen, V., Kurtén, T., Ortega, I. K., Vehkamäki, H., Pádua, A. A. H., Sellegri, K., and Kulmala, M.: Enhancing effect of dimethylamine in sulfuric acid nucleation in the presence of water - a computational study, Atmos. Chem. Phys., 10, 49614974, doi:10.5194/acp-10-4961-2010, 2010.

Lucas, D. D. and Akimoto, H.: Evaluating aerosol nucleation parameterizations in a global atmospheric model, Geophys. Res. Lett., 33, L10808, doi:10.1029/2006GL025672, 2006.

Manninen, H. E., Petäjä, T., Asmi, E., Riipinen, I., Nieminen, T., Mikkilä, J., Hõrrak, U., Mirme, A., Mirme, S., Laakso, L., Kerminen, V.-M., and Kulmala M.: Long-term field measurements of charged and neutral clusters using Neutral cluster and Air Ion Spectrometer (NAIS), Boreal Environ. Res., 14, 591-605, 2009a. Manninen, H. E., Nieminen, T., Riipinen, I., Yli-Juuti, T., Gagné,
S., Asmi, E., Aalto, P. P., Petäjä, T., Kerminen, V.-M., and Kulmala, M.: Charged and total particle formation and growth rates during EUCAARI 2007 campaign in Hyytiälä, Atmos. Chem. Phys., 9, 4077-4089, doi:10.5194/acp-9-4077-2009, 2009b.

Manninen, H. E., Nieminen, T., Asmi, E., Gagné, S., Häkkinen, S., Lehtipalo, K., Aalto, P., Vana, M., Mirme, A., Mirme, S., Hõrrak, U., Plass-Dülmer, C., Stange, G., Kiss, G., Hoffer, A., Töro, N., Moerman, M., Henzing, B., de Leeuw, G., Brinkenberg, M., Kouvarakis, G. N., Bougiatioti, A., Mihalopoulos, N., O'Dowd, C., Ceburnis, D., Arneth, A., Svenningsson, B., Swietlicki, E., Tarozzi, L., Decesari, S., Facchini, M. C., Birmili, W., Sonntag, A., Wiedensohler, A., Boulon, J., Sellegri, K., Laj, P., Gysel, M., Bukowiecki, N., Weingartner, E., Wehrle, G., Laaksonen, A., Hamed, A., Joutsensaari, J., Petäjä, T., Kerminen, V.-M., and Kulmala, M.: EUCAARI ion spectrometer measurements at 12 European sites - analysis of new particle formation events, Atmos. Chem. Phys., 10, 7907-7927, doi:10.5194/acp-10-79072010, 2010.

Makkonen, R., Asmi, A., Korhonen, H., Kokkola, H., Järvenoja, S., Räisänen, P., Lehtinen, K. E. J., Laaksonen, A., Kerminen, V.M., Järvinen, H., Lohmann, U., Bennartz, R., Feichter, J., and Kulmala, M.: Sensitivity of aerosol concentrations and cloud properties to nucleation and secondary organic distribution in ECHAM5-HAM global circulation model, Atmos. Chem. Phys., 9, 1747-1766, doi:10.5194/acp-9-1747-2009, 2009.

McMurry, P. H.: The history of condensation nucleus counters, Aerosol Sci. Tech., 33, 297-322, 2000.

McMurry, P. H. and Friedlander, S. K.: New particle formation in the presence of aerosol, Atmos. Environ., 13, 1635-1651, 1979.

McMurry, P., Fink, M, Sakurai, H., Stolzenburg, M., Mauldin, L., Moore, K., Smith, J., Eisele, F., Sjostedt, S., and Tanner, D.: A criterion for new particle formation in -rich Atlanta atmosphere, J. Geophys. Res., 110, D22S02, doi:10.1029/2005JD005901, 2005.

Mentel, Th. F., Wildt, J., Kiendler-Scharr, A., Kleist, E., Tillmann, R., Dal Maso, M., Fisseha, R., Hohaus, Th., Spahn, H., Uerlings, R., Wegener, R., Griffiths, P. T., Dinar, E., Rudich, Y., and Wahner, A.: Photochemical production of aerosols from real plant emissions, Atmos. Chem. Phys., 9, 4387-4406, doi:10.5194/acp9-4387-2009, 2009.

Merikanto, J., Napari, I., Vehkamäki, H., Anttila, T., and Kulmala, M.: New parameterization of sulfuric acid-ammonia-water ternary nucleation rates at tropospheric conditions, J. Geophys. Res., 112, D15207, doi:10.1029/2006JD007977, 2007.

Merikanto, J., Spracklen, D. V., Mann, G. W., Pickering, S. J., and Carslaw, K. S.: Impact of nucleation on global CCN, Atmos. Chem. Phys., 9, 8601-8616, doi:10.5194/acp-9-8601-2009, 2009.

Mertes, S., Schröder, F., and Wiedensohler, A.: The particle detection efficiency curve of the TSI-3010 CPC as a function of the temperature difference between saturator and condenser, Aerosol Sci. Tech., 23, 257-261, 1995.

Metzger, A., Verheggen, B., Dommen, J., Duplissy, J., Prevot, A. S., Weingartner, E., Riipinen, I., Kulmala, M., Spracklen, D. V., Carslaw, K. S., and Baltensperger, U.: Evidence for the role of organics in aerosol particle formation under atmospheric conditions, P. Natl. Acad. Sci., 107, 6646-6651, doi:10.1073/pnas.0911330107, 2010.

Mirme, A., Tamm, E., Mordas, G., Vana, M., Uin, J., Mirme, S., 
Bernotas, T., Laakso, L., Hirsikko, A., and Kulmala, M.: A widerange multi-channel Air Ion spectrometer, Boreal Environ. Res., 12, 247-264, 2007.

Mirme, S., Mirme, A., Minikin, A., Petzold, A., Hõrrak, U., Kerminen, V.-M., and Kulmala, M.: Atmospheric sub-3 nm particles at high altitudes, Atmos. Chem. Phys., 10, 437-451, doi:10.5194/acp-10-437-2010, 2010.

Modgil, M. S., Kumar, S., Tripathi, S. N., and Lovejoy, E. R.: A parameterization of ion-induced nucleation of ic acid and water for atmospheric conditions, J. Geophys. Res., 110, D19205, doi:10.1029/2004JD005475, 2005.

Mordas, G., Kulmala, M., Petäjä, T., Aalto, P. P., Matuleviius, V., Grigoraitis, V., Uleviius, V., Grauslys, V., Ukkonen, A., and Hämeri, K.: Design and performance characteristics of a condensation particle counter UF-02proto, Boreal Environ. Res., 10, 543-552, 2005.

Mordas, G., Sipilä, M., and Kulmala, M.: Nanometer Particle Detection by the Condensation Particle Counter UF-02proto, Aerosol Sci. Tech., 42, 521-527, 2008.

Nadykto, A. B., Al Natsheh, A., Yu, F. Q., Mikkelsen K. V., and Herb, J.: Computational quantum chemistry: A new approach to atmospheric nucleation, Adv. Quantum Chem., 55, 449-478, 2008.

Napari, I., Noppel, M., Vehkamäki, H., and Kulmala, M.: Parametrization of ternary nucleation rates for $\mathrm{H}_{2} \mathrm{SO}_{4}$ $\mathrm{NH}_{3}-\mathrm{H}_{2} \mathrm{O}$ vapors, J. Geophys. Res., 107(D19), 4381, doi:10.1029/2002JD002132, 2002.

O'Dowd, C. D.: Biogenic coastal aerosol production and its influence on aerosol radiative properties, J. Geophys. Res., 106, 1545-1549, 2001.

Ortega, I. K., Kurtén, T., Vehkamki, H., and Kulmala, M.: The role of ammonia in sulfuric acid ion induced nucleation, Atmos. Chem. Phys., 8, 2859-2867, doi:10.5194/acp-8-2859-2008, 2008.

Paasonen, P.; Sihto, S.-L., Nieminen, T., Vuollekoski, H., Riipinen, I., Plass-Dülmer, C., Berresheim, H., Birmili, W., and Kulmala, M.: Connection between new particle formation and sulfuric acid at Hohenpeissenberg (Germany) including the influence of organic compounds, Boreal Environ. Res., 14, 616-629, 2009.

Paasonen, P., Nieminen, T., Asmi, E., Manninen, H. E., Petäjä, T., Plass-Dülmer, C., Flentje, H., Birmili, W., Wiedensohler, A., Hõrrak, U., Metzger, A., Hamed, A., Laaksonen, A., Facchini, M. C., Kerminen, V.-M., and Kulmala, M.: On the roles of sulphuric acid and low-volatility organic vapours in the initial steps of atmospheric new particle formation, Atmos. Chem. Phys. Discuss., 10, 11795-11850, doi:10.5194/acpd-10-117952010, 2010.

Petäjä, T., Mordas, G., Manninen, H., Aalto, P. P., Hämeri, K., and Kulmala, M.: Detection efficiency of a water-based TSI Condensation Particle Counter 3785, Aerosol Sci. Tech., 40, 1090-1097, 2006.

Petäjä, T., Mauldin, III, R. L., Kosciuch, E., McGrath, J., Nieminen, T., Paasonen, P., Boy, M., Adamov, A., Kotiaho, T., and Kulmala, M.: Sulfuric acid and $\mathrm{OH}$ concentrations in a boreal forest site, Atmos. Chem. Phys., 9, 7435-7448, doi:10.5194/acp9-7435-2009, 2009.

Pierce, J. R. and Adams, P. J.: Efficiency of cloud condensation nuclei formation from ultrafine particles, Atmos. Chem. Phys., 7, 1367-1379, doi:10.5194/acp-7-1367-2007, 2007.
Pierce, J. R. and Adams, P. J.: Uncertainty in global CCN concentrations from uncertain aerosol nucleation and primary emission rates, Atmos. Chem. Phys., 9, 1339-1356, doi:10.5194/acp-91339-2009, 2009.

Pöschl, U., Rudich, Y., and Ammann, M.: Kinetic model framework for aerosol and cloud surface chemistry and gas-particle interactions - Part 1: General equations, parameters, and terminology, Atmos. Chem. Phys., 7, 5989-6023, doi:10.5194/acp-75989-2007, 2007.

Riipinen, I., Sihto, S.-L., Kulmala, M., Arnold, F., Dal Maso, M., Birmili, W., Saarnio, K., Teinilä, K., Kerminen, V.-M., Laaksonen, A., and Lehtinen, K. E. J.: Connections between atmospheric sulphuric acid and new particle formation during QUEST III-IV campaigns in Heidelberg and Hyytiälä, Atmos. Chem. Phys., 7, 1899-1914, doi:10.5194/acp-7-1899-2007, 2007.

Riipinen, I., Manninen, H. E., Yli-Juuti, T., Boy, M., Sipilä, M., Ehn, M., Junninen, H., Petäjä, T., and Kulmala, M.: Applying the Condensation Particle Counter Battery (CPCB) to study the water-affinity of freshly-formed $29 \mathrm{~nm}$ particles in boreal forest, Atmos. Chem. Phys., 9, 3317-3330, doi:10.5194/acp-9-33172009, 2009.

Russell, L. M., Pandis, S. N., and Seinfeld, J. H.: Aerosol production and growth in the marine boundary layer, J. Geophys. Res., 99, 20989-21003, 1994.

Saros, M., Weber, R. J., Marti, J., and McMurry, P. H.: Ultra fine aerosol measurement using a condensation nucleus counter with pulse height analysis, Aerosol Sci. Tech., 25, 200-213, 1996.

Shiraiwa, M., Garland, R. M., and Pöschl, U.: Kinetic double-layer model of aerosol surface chemistry and gas-particle interactions (K2-SURF): Degradation of polycyclic aromatic hydrocarbons exposed to $\mathrm{O}_{3}, \mathrm{NO}_{2}, \mathrm{H}_{2} \mathrm{O}, \mathrm{OH}$ and $\mathrm{NO}_{3}$, Atmos. Chem. Phys., 9, 9571-9586, doi:10.5194/acp-9-9571-2009, 2009.

Shiraiwa, M., Pfrang, C., and Pöschl, U.: Kinetic multi-layer model of aerosol surface and bulk chemistry (KM-SUB): the influence of interfacial transport and bulk diffusion on the oxidation of oleic acid by ozone, Atmos. Chem. Phys., 10, 3673-3691, doi:10.5194/acp-10-3673-2010, 2010.

Sihto, S.-L., Kulmala, M., Kerminen, V.-M., Dal Maso, M., Petäjä, T., Riipinen, I., Korhonen, H., Arnold, F., Janson, R., Boy, M., Laaksonen, A., and Lehtinen, K. E. J.: Atmospheric sulphuric acid and aerosol formation: implications from atmospheric measurements for nucleation and early growth mechanisms, Atmos. Chem. Phys., 6, 4079-4091, doi:10.5194/acp-6-4079-2006, 2006.

Sipilä, M., Lehtipalo, K., Kulmala, M., Petäj, T., Junninen, H., Aalto, P. P., Manninen, H. E., Kyrö, E.-M., Asmi, E., Riipinen, I., Curtius, J., Krten, A., Borrmann, S., and O'Dowd, C. D.: Applicability of condensation particle counters to measure atmospheric clusters, Atmos. Chem. Phys., 8, 4049-4060, doi:10.5194/acp-8-4049-2008, 2008.

Sipilä, M., Lehtipalo, K., Attoui, M., Neitola, K., Petäjä, T., Aalto, P. P., O'Dowd, C. D., and Kulmala, M.: Laboratory verification of PH-CPC's ability to monitor atmospheric sub-3nm clusters, Aerosol Sci. Tech., 43, 126-135, 2009.

Sipilä, M., Berndt, T., Petäjä, T., Brus, D., Vanhanen, J., Stramann, F., Patokoski, J., Mauldin III, R. L., Hyvärinen, A.P., Lihavainen, H., and Kulmala, M.: The role of sulfuric acid in atmospheric nucleation, Science, 327, 1243-1246, doi:10.1126/science.1180315, 2010. 
Sgro, L.A. and Fernández de la Mora, J.: A simple turbulent mixing $\mathrm{CNC}$ for charged particle detection down to $1.2 \mathrm{~nm}$, Aerosol Sci. Tech., 38, 1-11, 2004.

Smith, J. N., Dunn, M. J., VanReken, T. M., Iida, K., Stolzenburg, M. R., McMurry, P. H., and Huey, L. G.: Chemical composition of atmospheric nanoparticles formed from nucleation in Tecamac, Mexico: Evidence for an important role for organic species in nanoparticle growth, Geophys. Res. Lett., 35, L04808, doi:10.1029/2007GL032523, 2008.

Spracklen, D. V., Carslaw, K. S., Kulmala, M., Kerminen, V.-M., Mann, G. W., and Sihto, S.-L.: The contribution of boundary layer nucleation events to total particle concentrations on regional and global scales, Atmos. Chem. Phys., 6, 5631-5648, doi:10.5194/acp-6-5631-2006, 2006.

Spracklen, D. V., Carslaw, K. S., Kulmala, M., Kerminen, V.-M., Sihto, S.-L., Riipinen, I., Merikanto, J., Mann, G. W., Chipperfield, M. P., Wiedensohler, A., Birmili, W., and Lihavainen, H.: Contribution of particle formation to global cloud condensation nuclei concentrations, Geophys. Res. Lett., 35, L06808, doi:10.1029/2007GL033038, 2008.

Stolzenburg, M. R. and McMurry, P. H.: An ultrafine aerosol condensation nucleus counter, Aerosol Sci. Tech., 14, 48-65, 1991.

Suni, T., Kulmala, M., Hirsikko, A., Bergman, T., Laakso, L., Aalto, P. P., Leuning, R., Cleugh, H., Zegelin, S., Hughes, D., van Gorsel, E., Kitchen, M., Vana, M., Hõrrak, U., Mirme, S., Mirme, A., Sevanto, S., Twining, J., and Tadros, C.: Formation and characteristics of ions and charged aerosol particles in a native Australian Eucalypt forest, Atmos. Chem. Phys., 8, 129-139, doi:10.5194/acp-8-129-2008, 2008.

Tammet, H. and Kulmala, M.: Simulation tool for atmospheric aerosol bursts, J. Aerosol Sci., 36, 173-196, 2005.

Tammet, H., Hõrrak, U., and Kulmala, M.: Negatively charged nanoparticles produced by splashing of water, Atmos. Chem. Phys., 9, 357-367, doi:10.5194/acp-9-357-2009, 2009.

Turco, R. P., Zhou, J.-X., and Yu, F.: A new source of tropospheric aerosols: Ion-ion recombination, Geophys. Res. Lett., 25, 635638,1998

Ude, S. and de la Mora, J. F.: Molecular monodisperse mobility and mass standards from electrosprays of tetra-alkyl ammonium halides, J. Aerosol Sci., 36, 1224-1237, 2005.

Wang, S. C. and Flagan, R. C.: Scanning Electrical Mobility Spectrometer, Aerosol Sci. Tech., 13, 230-240, 1990.

Wang, M. and Penner, J. E.: Aerosol indirect forcing in a global model with particle nucleation, Atmos. Chem. Phys., 9, 239-260, doi:10.5194/acp-9-239-2009, 2009.

Vanhanen, J., Mikkilä, J., Sipilä, M., Manninen, H. E., Lehtipalo, K., Siivola, E., Petäjä, T., and Kulmala, M.: Particle Size Magnifier for nano-CN detection, Aerosol Sci. Tech., accepted, 2010.

Weber, R. J., Marti, J. J., McMurry, P. H., Eisele, F. L., Tanner, D. $\mathrm{J}$, and Jefferson A.: Measured atmospheric new particle formation rates: Implications for nucleation mechanisms, Chem. Eng. Commun., 151, 53-64, 1996.

Vehkamäki, H., Kulmala, M., Napari, I., Lehtinen, K .E. J., Timmreck, C., Noppel, M., and Laaksonen, A.: An improved parameterization for sulfuric acid-water nucleation rates for tropospheric and stratospheric conditions, J. Geophys. Res., 107(D22), 4622, doi:10.1029/2002JD002184, 2002.
Venzac, H., Sellegri, K., and Laj, P.: Nucleation events detected at the high altitude site of the Puy de Dome Research Station, France, Boreal Environ. Res., 12, 345-359, 2007.

Whitehead, J. D., McFiggans G. B., Gallagher, M. W., and Flynn, M. J.: Direct linkage between tidally driven coastal ozone deposition fluxes, particle emission fluxes, and subsequent CCN formation, Geophys. Res. Lett., 36, L04806, doi:10.1029/2008GL035969, 2009.

Wiedensohler, A.: An approximation of the bipolar charge distribution for particles in the submicron size range, J. Aerosol Sci., 19, 387-389, 1988.

Wiedensohler, A., Cheng, Y. F., Nowak, A., Wehner, B., Achtert, P., Berghof, M., Birmili, W., Wu, Z. J., Hu, M., Zhu, T., Takegawa, N., Kita, K., Kondo, Y., Lou, S. R., Hofzumahaus, A., Holland, F., Wahner, A., Gunthe, S. S., Rose, D., Su, H., and Pöschl, U.: Rapid aerosol particle growth and increase of cloud condensation nucleus activity by secondary aerosol formation and condensation: A case study for regional air pollution in northeastern China, J. Geophys. Res., 114, D00G08, doi:10.1029/2008JD0101884, 2009.

Winkler, P. M., Steiner, G., Vrtala, A., Vehkamäki, H., Noppel, M., Lehtinen, K. E. J., Reischl, G. P., Wagner, P. E., and Kulmala, M.: Heterogeneous nucleation experiments bridging the scale from molecular ion clusters to nanoparticles, Science, 319, 1374-1377, doi:10.1126/science.1149034, 2008a.

Winkler, P. M., Vrtala, A., and Wagner, P. E.: Condensation particle counting below $2 \mathrm{~nm}$ seed particle diameter and the transition from heterogeneous to homogeneous nucleation, Atmos. Res., 90, 125-131, 2008b.

Vuollekoski, H., Kerminen, V.-M., Anttila, T., Sihto, S.-L., Vana, M., Ehn, M., Korhonen, H., McFiggans, G., O’Dowd, C. D., and Kulmala, M.: Iodine dioxide nucleation simulations in coastal and remote marine environments, J. Geophys. Res., 114, D02206, doi:10.1029/2008JD010713, 2009.

$\mathrm{Yu}$, F.: Updated $\mathrm{H}_{2} \mathrm{SO}_{2}-\mathrm{H}_{2} \mathrm{O}$ binary homogeneous nucleation look-up tables, J. Geophys. Res., 113, D24201, doi:10.1029/2008JD010527, 2008.

Yu, F.: Ion-mediated nucleation in the atmosphere: Key controlling parameters, implications, and look-up table, J. Geophys. Res., 115, D03206, doi:10.1029/2009JD012630, 2010.

Yu, F. and Luo, G.: Simulation of particle size distribution with a global aerosol model: contribution of nucleation to aerosol and CCN number concentrations, Atmos. Chem. Phys., 9, 76917710, doi:10.5194/acp-9-7691-2009, 2009.

Yu, F. and Turco, R.: Case studies of particle formation events observed in boreal forests: implications for nucleation mechanisms, Atmos. Chem. Phys., 8, 6085-6102, doi:10.5194/acp-86085-2008, 2008.

Zhang, R., Suh, I., Zhao, J., Zhang, D., Fortner, E. C., Tie, X., Molina, L. T., and Molina, M. J.: Atmospheric new particle formation enhanced by organic acids, Science, 304, 1487-1490, 2004.

Zhao, J., Eisele, F. L., Titcombe, M., Kuang, C., and McMurry, P. H.: Chemical ionization mass spectrometric measurements of atmospheric neutral clusters using the cluster-CIMS, J. Geophys. Res., 115, D08205, doi:10.1029/2009JD012606, 2010. 